Article

\title{
Dissolved and Suspended Forms of Metals and Metalloids in Snow Cover of Megacity: Partitioning and Deposition Rates in Western Moscow
}

\author{
Dmitry Vlasov*(D), Jessica Vasil'chuk ${ }^{(D)}$, Natalia Kosheleva and Nikolay Kasimov \\ Faculty of Geography, Lomonosov Moscow State University, 119991 Moscow, Russia; \\ jessica.vasilchuk@gmail.com (J.V.); natalk@mail.ru (N.K.); nskasimov@mail.ru (N.K.) \\ * Correspondence: vlasov.msu@gmail.com
}

Received: 12 July 2020; Accepted: 24 August 2020; Published: 26 August 2020

\begin{abstract}
Concentrations and ratio of dissolved and suspended forms of metals and metalloids (MMs) in snow cover and their deposition rates from the atmosphere in the western part of Moscow were studied. Forms of MMs were separated using a filter with pore diameter of $0.45 \mu \mathrm{m}$; their concentrations were measured by ICP-MS and ICP-AES methods. Anthropogenic impact in Moscow caused a significant increase in dust load (2-7 times), concentration of solid particles in snow cover (2-5 times), and mineralization of snow meltwater (5-18 times) compared to the background level. Urban snow contains $\mathrm{Sn}, \mathrm{Ti}, \mathrm{Bi}, \mathrm{Al}, \mathrm{W}, \mathrm{Fe}, \mathrm{Pb}, \mathrm{V}, \mathrm{Cr}, \mathrm{Rb}, \mathrm{Mo}, \mathrm{Mn}, \mathrm{As}, \mathrm{Co}, \mathrm{Cu}, \mathrm{Ba}$, Sb, Mg mainly in suspended form, and $\mathrm{Ca}$ and $\mathrm{Na}$ in dissolved form. The role of suspended MMs in the city significantly increases compared to the background region due to high dust load, usage of de-icing salts, and the change of acidic background conditions to alkaline ones. Anthropogenic emissions are the main sources of suspended $\mathrm{Ca}, \mathrm{W}, \mathrm{Co}, \mathrm{V}, \mathrm{Sr}, \mathrm{Ti}, \mathrm{Mg}, \mathrm{Na}, \mathrm{Mo}, \mathrm{Zn}, \mathrm{Fe}, \mathrm{Sb}$, and $\mathrm{Cu}$ in the snow cover of traffic zone. These elements' concentrations in roadside snow cover exceed the background values more than 25 times. The highest concentrations and deposition rates of MMs in the snow of Moscow are localized near the large and medium roads.
\end{abstract}

Keywords: urban pollution; partitioning; metals; solubility; atmospheric depositions; snow pollution; source identification

\section{Introduction}

Urban air pollution with particulate matter is a recognized environmental problem, especially relevant for megacities. Contaminated air is responsible for about $80 \%$ of premature deaths; it causes ischaemic heart disease, stroke, chronic obstructive pulmonary disease, and lung cancer [1], and increases the risk of adenocarcinomas [2]. Increased concentrations of particulate matter with high proportions of metals and metalloids (MMs) affect the external respiratory function of citizens, especially of asthma patients [3].

Due to its long occurrence and ability to accumulate pollutants over the entire cold period of the year, snow cover is a natural, informative, and convenient component indicating air pollution with particulate matter and MMs in northern cities [4-7]. Snow pollution with MMs correlates well with the overall Air Quality Index (AQI) and the level of atmospheric pollution with $\mathrm{PM}_{10}$ and $\mathrm{PM}_{2.5}$ [8]. In comparison to rains, snow more effectively absorbs pollutants and washes them out of the atmosphere due to the higher surface area and porosity of snowflakes compared to raindrops [9]. The intensity of snow cover pollution is determined from the mass of MMs entering soils and surface waters during snow melting. MMs in liquid (dissolved or soluble) form could be included into the biogeochemical cycle, while solid (suspended or insoluble) forms of MMs accumulate in surface 
horizons of urban soils and road dust [10-12]. The ratio of these forms of MMs and its variations are also frequently used informative indicators of different types of pollution sources [13-16]. In recent studies on snow cover pollution, special attention has been paid to the chemical composition of accumulated particulate matter and the determination of its mass [4,17-22].

Major sources of pollutants in the snow cover of cities are emissions of vehicles, industries and the fuel and energy complex, as well as de-icing salts (DISs). High level of snow cover pollution along roads is caused by reduced efficiency of automobile engines when air temperatures are below zero $[23,24]$. The most often used chemical DISs are chlorides and carbonates of $\mathrm{Na}, \mathrm{Ca}, \mathrm{Mg}$, and $\mathrm{K}$, as well as organic compounds, glycols and other alcohols, etc. $[25,26]$. However, the most commonly applied $\mathrm{NaCl}$ causes salinization and solonetzicity of soils, suppresses urban vegetation, and increases salinity of water bodies [27-31]. During snow melting, chloride meltwater increases the mobility of many metals contained in soil particles and their environmental hazard, probably due to the formation of MMs chlorides [32-34].

Moscow is the largest megacity in Europe, with more than 12.6 million citizens, and more than 17 million people inhabiting the agglomeration. As in many other large cities the main source of anthropogenic impact on the environment is motor transport, generating about $93 \%$ of the total emissions to the atmosphere. Heat and power stations and the oil refinery are responsible for the majority of stationary source emissions [35]. In spite of active deindustrialization since the 1990s, industrial zones still occupy about $17 \%$ of the city area, thus reducing the connectivity of road network and leading to excessive motor traffic and higher release of pollutants [36,37].

The studies of snow cover pollution in certain administrative okrugs and districts of Moscow and the Moscow Oblast are quite numerous [29,30,38-50]. However, most of the studies did not consider the ratio of MMs forms (i.e., MMs partitioning) and its change under anthropogenic impact; nor did they include comprehensive assessment of snow cover pollution with MMs near roads of different types. It is therefore necessary to collect and constantly update data about geochemical pressure on urban landscapes, especially in the traffic zone.

The western part of Moscow is considered to be less polluted with industrial emissions due to predominant westerlies and the concentration of large industrial zones in the eastern and southeastern sectors of the city, where they produce about $2 / 3$ of the total industrial emissions [36]. Therefore, the Western Administrative Okrug (WAO), with a population of 1.4 million and with about 2800 cars per $1 \mathrm{~km}^{2}$, was chosen to assess the vehicles' impact on MMs accumulation in snow [35]. Our main objective is to assess anthropogenically-induced changes in the chemical composition of snow cover in the traffic zone of the WAO. The aims of this study were the following: (1) identification of changes in macro-component composition and physical-chemical properties of the snow meltwater in the WAO relative to the background territory; (2) determination of snow cover contamination by dissolved and suspended forms of MMs near roads and at car parking lots in the yards of residential buildings; (3) analysis of the ratio of MMs forms in the snow cover of the traffic zone; (4) assessment of the atmospheric deposition rates of pollutants along the roads and potential anthropogenic load on the urban landscapes of WAO during snow melting.

\section{Materials and Methods}

\subsection{Study Area and Snow Sampling}

Southerly and westerly winds prevail in Moscow during the year, resulting in the regional transfer of pollutants in the north and east directions; the repeatability of easterly winds is also high [51]. Moreover, Moscow is a "heat island", created by burning the great amount of fuel from the end of September to the second half of April [52]. The resulting upward air currents in the city center promote the inflow of relatively clean air from suburban territories to the city. This contributes to self-purification of the atmospheric air and, consequently, diminishes snow cover pollution [53]. 
Large highways and interchanges (Moscow Ring Road-MRR, Rublevskoye and Mozhaiskoye highways, Kutuzovskiy and Michurinskiy avenues, etc.) are the main sources of anthropogenic impact in WAO. There are also six industrial zones within its territory: Fili (Figure 1, letter (A)), Western Port (B), Berezhkovskaya Embankment (C), Kuntsevo (D), Severnoye Ochakovo (E), and Yuzhnoye Ochakovo (F), which include heat and power stations No. 25 (Severnoye Ochakovo industrial zone) and No. 12 (Berezhkovskaya Embankment industrial zone), metal-fabricating enterprises, electrical equipment production, enterprises of rubber, chemical, light and food industries (Figure 1).

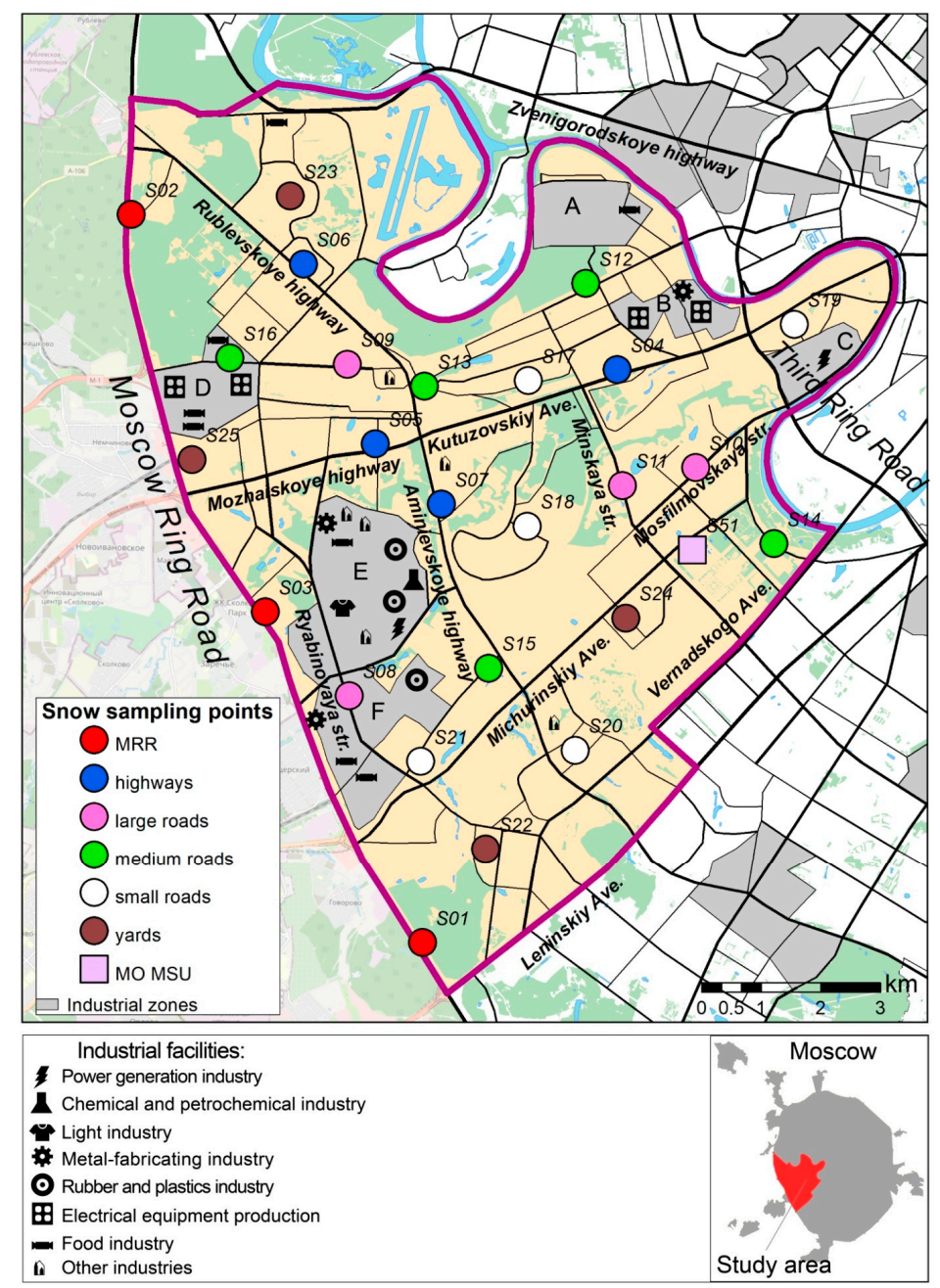

Figure 1. Snow cover sampling sites in the western part of Moscow (March 2018). Industrial zones: A-Fili, B-Western Port, C-Berezhkovskaya Embankment, D-Kuntsevo, E-Severnoye Ochakovo, F-Yuzhnoye Ochakovo.

Geochemical survey of snow cover was carried out in mid-March 2018 in maximum snow cover thickness. Due to frequent thawing weather in winter of 2017-2018, permanent snow cover was formed only at the end of the first decade of January 2018. The thickness of snow cover in WAO differed only slightly from the long-term mean values $(35-45 \mathrm{~cm})[51,54]$ and averaged $42-50 \mathrm{~cm}$ near roads, increasing to $55-65 \mathrm{~cm}$ (averaged $61 \mathrm{~cm}$ ) within the background areas. It is known that MMs concentrations in the surface layer of snow cover are usually lower than in the underlying layers [12]. To avoid underestimation of snow cover pollution, snow samples were taken along the full depth of undisturbed snow cover. In total, 26 mixed samples were taken within the territory of WAO (Figure 1), each consisting of 10-15 individual samples taken at a distance of 3-5 $\mathrm{m}$ by plastic pipe with the cross-section area of $20 \mathrm{~cm}^{2}$ (one plastic pipe corresponded to one snow core, i.e., snow column) along the following roads: the MRR (3 sites), highways with four lanes in one direction (4 sites), 
large roads with three lanes in one direction (4 sites), medium roads with two lanes in one direction (5 sites), and small roads with one lane in one direction (5 sites). The yards of residential buildings with car parking lots (four sites) and the Meteorological Observatory of the Lomonosov Moscow State University (MO MSU) were also sampled. The background area was chosen to be sufficiently distant from the city to avoid its polluting influence. Thus, three sampling sites were selected more than $120 \mathrm{~km}$ west of Moscow in the Mozhaisk and Volokolamsk districts of the Moscow Oblast.

\subsection{Laboratory Analysis and Data Processing}

Snow cover samples were melted in the laboratory at $20-22{ }^{\circ} \mathrm{C}$. The main physicochemical characteristics of meltwater were determined at the Ecological and Geochemical Center of the Lomonosov Moscow State University, Faculty of Geography. The $\mathrm{pH}$ of the resulting solution was measured using the potentiometric method with the pHMeter "SevenCompact S220" (Mettler Toledo, Greifensee, Switzerland; accuracy: \pm 0.002$)$. Filtration through membrane filters with pore diameter of $0.45 \mu \mathrm{m}$ (EMD Millipore, Burlington, MA, USA) was applied to isolate filtrate with dissolved (or soluble) forms of MMs and particles on the filter with suspended (or insoluble) forms. Filters with pore diameter of $0.45 \mu \mathrm{m}$ are widely used to separate the dissolved and suspended forms of MMs when studying the composition of snow cover, rainfall runoff, or river waters $[8,16,55,56]$.

The anionic composition of filtrate $\left(\mathrm{SO}_{4}{ }^{2-}, \mathrm{Cl}^{-}, \mathrm{NO}_{3}{ }^{-}\right)$was determined using the "Stayer" liquid ion chromatograph (Akvilon, Moscow, Russia); and the cationic composition $\left(\mathrm{Ca}^{2+}, \mathrm{Mg}^{2+}, \mathrm{K}^{+}, \mathrm{Na}^{+}\right)$using the atomic absorption spectrometer with flame atomization "novAA-400" (Analytik-Jena AG, Jena, Germany). The detection limits for cations and anions were calculated at 95\% confidence level for three parallel measurements of the sample and blank measurements. For $\mathrm{SO}_{4}{ }^{2-}$ and $\mathrm{Na}^{+}$, they are $0.04 \mathrm{mg} / \mathrm{L}$, for $\mathrm{Ca}^{2+}$ and $\mathrm{K}^{+}-0.03 \mathrm{mg} / \mathrm{L}$, for $\mathrm{Cl}^{-}, \mathrm{NO}_{3}{ }^{-}$, and $\mathrm{Mg}^{2+}-0.02 \mathrm{mg} / \mathrm{L}$. The concentration of $\mathrm{HCO}_{3}{ }^{-}$ ions was calculated as the difference between the sums of cations and anions equivalents. In aerosol chemistry, the ammonium plays a significant role in chemical processes, including the formation of secondary ammonium sulfate and ammonium nitrate fine inorganic aerosols [57]. However, previous studies on the chemical composition of snow in Moscow showed that the ammonium in urban snow is about $5 \%$-eq. from the amount of cations [58]. That is, the ammonium does not play a significant role in the balance of cations in Moscow snow meltwater. Therefore, the concentrations of ammonium in snow cover of WAO were not measured.

The content of solid particles in snow meltwater $(X, \mathrm{mg} / \mathrm{L})$ was estimated (Equation (1)) based on the mass of suspension on the filter $m(\mathrm{mg})$, weighed on an analytical balance "Discovery DV114C" (Ohaus, Greifensee, Switzerland; repeatability: $0.1 \mathrm{mg}$ ):

$$
X=m / V,
$$

where $V$ is the amount of meltwater $(\mathrm{L})$.

Concentrations of dissolved and suspended forms of $\mathrm{Al}, \mathrm{As}, \mathrm{Ba}, \mathrm{Bi}, \mathrm{Ca}, \mathrm{Cd}, \mathrm{Co}, \mathrm{Cr}, \mathrm{Cu}, \mathrm{Fe}$, $\mathrm{K}, \mathrm{Mg}, \mathrm{Mn}, \mathrm{Mo}, \mathrm{Na}, \mathrm{Ni}, \mathrm{Pb}, \mathrm{Rb}, \mathrm{Sb}, \mathrm{Sn}, \mathrm{Sr}, \mathrm{Ti}, \mathrm{V}, \mathrm{W}$, and $\mathrm{Zn}$ were measured at the laboratory of the N.M. Fedorovsky All-Russian Research Institute of Mineral Raw Materials (VIMS) by ICP-MS and ICP-AES methods using the "iCAP Qc" mass spectrometer (Thermo Fisher Scientific, Waltham, MA, USA) and the "Optima-4300DV" atomic emission spectrometer (Perkin Elmer, Waltham, MA, USA) according to the certified methods [59,60]. The VIMS laboratory is accredited to the Analytics international accreditation system (AAS.A.00255) and the national accreditation system (RA.RU.21ГП11); it meets the requirements of the International Standards ISO Guide 34:2009, ISO/IEC 17025:2017, and ISO/IEC 17043:2010. The VIMS laboratory is also accredited to certificate measurement techniques and provide metrological examination in Russian Federation (accreditation certificate No. 01.00115-2013). The analysis was conducted using replicates, method blanks, field blanks, and standard reference materials in order to maintain the standard quality. For dissolved MMs, the detection limit (DL), which is defined as three times the standard deviation of replicate blank measurements, were as 
$(\mu \mathrm{g} / \mathrm{L}): \mathrm{Na}, 18 ; \mathrm{Mg}, 100 ; \mathrm{Al}, 0.57 ; \mathrm{K}, 100 ; \mathrm{Ca}, 19 ; \mathrm{Ti} 0.55 ; \mathrm{V}, 0.4 ; \mathrm{Cr}, 1.0 ; \mathrm{Mn}, 0.33 ; \mathrm{Fe}, 0.53 ; \mathrm{Co}, 0.034 ; \mathrm{Ni}$, 3.4; Cu, 0.32; Zn, 0.23; As, 0.10; Rb, 0.005; Sr, 0.02; Mo, 0.05; Cd, 0.004; Sn, 0.01; Sb, 0.007; Ba, 0.01; W, $0.03 ; \mathrm{Pb}, 0.05 ; \mathrm{Bi}, 0.002$. For suspended MMs the DL were as $(\mu \mathrm{g} / \mathrm{L}): \mathrm{Na}, 16 ; \mathrm{Mg}, 2.2 ; \mathrm{Al}, 22 ; \mathrm{K}, 9.1 ; \mathrm{Ca}$, 25; Ti, 1.6; V, 0.12; Cr, 0.38; Mn, 0.18; Fe, 8.6; Co, 0.01; Ni, 0.29; Cu, 0.52; Zn, 1.0; As, 0.02; Rb, 0.01; Sr, 0.12; Mo, 0.009; Cd, 0.001; Sn, 0.08; Sb, 0.005; Ba, 0.31; W, 0.05; Pb, 0.6; Bi, 0.003 .

Snow cover contamination with dissolved and suspended forms of MMs was evaluated (Equation (2)) using the contamination factor $(C F)$ :

$$
C F=C u r b / C b
$$

where $\mathrm{Curb}$ and $\mathrm{Cb}$ are MMs concentrations in snow cover in the city and in the background area, respectively $(\mu \mathrm{g} / \mathrm{L})$.

The mass of each MMs coming to the Earth's surface from the atmosphere ( $\mu \mathrm{g} / \mathrm{m}^{2}$ per day), that is, the deposition rates of suspended and dissolved MMs were calculated (Equations (3) and (4)):

$$
\begin{aligned}
\text { Durb } & =\text { Curb } \cdot P / t \\
D b & =C b \cdot P / t
\end{aligned}
$$

where Durb and $D b$ are deposition rates in the city and in the background area, respectively $\left(\mu \mathrm{g} / \mathrm{m}^{2}\right.$ per day); $P$ is the water supply in snow cover $\left(\mathrm{L} / \mathrm{m}^{2}\right) ; t$ is the number of days of snow cover occurrence (61-63 days depending on the date of snow sampling).

Water supply in snow cover was calculated according to Equation (5) below:

$$
P=V /(a \cdot t \cdot S)
$$

where $a$ is the number of plastic pipes with snow (i.e., snow columns or snow cores) collected at the site; $S$ is the area of the plastic pipe cross-section, $\mathrm{m}^{2}$.

The dust deposition rate was estimated as (Equation (6)):

$$
P n=m /(a \cdot t \cdot S)
$$

The intensity of anthropogenic pressure was determined (Equation (7)) as the excess of an element deposition rate on the studied urban area over its deposition rate on the background area:

$$
D F=D u r b / D b .
$$

Comprehensive assessment of snow cover pollution with dissolved and suspended MMs was obtained by calculating the total contamination factor of snow (TCF, Equation (8)) and the total excess of MMs deposition rates in the city above the background (TDF, Equation (9)):

$$
\begin{aligned}
& T C F=\sum C F-(n-1), \\
& T D F=\sum D F-(n-1),
\end{aligned}
$$

where $n$ is the number of chemical elements with $C F$ or $D F>1$; when calculating TCF and TDF, only $C F$ and $D F>1$ are summed [61,62]. The environmental hazard of MMs snow pollution was determined in line with the TCF gradations adopted in Russia: <32-low, non-dangerous, 32-64-medium, moderately dangerous, 64-128-high, dangerous, 128-256-very high, very dangerous, >256-maximum, extremely dangerous [61,62].

The spatial distribution patterns of the TCF and TDF totals were evaluated in the ArcGIS software package (Esri, Redlands, CA, USA). Cluster analysis to separate stable paragenetic associations of MMs was performed by the Complete Linkage method in the STATISTICA 8 software (Statsoft/Dell, 
Tulsa, OK, USA) with a measure of similarity $d=1$-Person $r$ and amalgamation rule Complete Linkage. The significance of Pearson correlation coefficients $r$ and Spearman correlation coefficients $r_{s}$ was checked against the $t$-criterion at $p<0.05$.

\section{Results and Discussion}

\subsection{Physicochemical Properties and Macrocomposition of Snow Meltwater}

Background snow waters in the western part of Moscow are slightly acidic (pH 5.6), with low mineralization $(6.4 \mathrm{mg} / \mathrm{L})$; the ionic composition of water is calcium bicarbonate (Table 1 ). The obtained data correlates with the findings of physicochemical properties of snow in Moscow suburbs $[40,58,63]$. The concentration of solid particles in snow water in background conditions is low (about $9 \mathrm{mg} / \mathrm{L}$ ), while the intensity of daily dust load $\left(9 \mathrm{mg} / \mathrm{m}^{2}\right.$ per day) corresponds to the average level for background non-urbanized areas in the East European Plain (about $10 \mathrm{mg} / \mathrm{m}^{2}$ per day) [61].

Table 1. Physicochemical properties, snow cover thickness, and ion content in snow meltwater in the western part of Moscow and the background territory.

\begin{tabular}{|c|c|c|c|c|c|c|c|c|c|}
\hline \multirow[b]{2}{*}{ Parameter } & \multicolumn{5}{|c|}{ Roads* } & \multirow[b]{2}{*}{$\begin{array}{c}\mathbf{R} \\
(n=21)\end{array}$} & \multirow[b]{2}{*}{$\begin{array}{c}Y \\
(n=4)\end{array}$} & \multirow[b]{2}{*}{$\begin{array}{l}\text { MO MSU } \\
\quad(n=1)\end{array}$} & \multirow[b]{2}{*}{$\begin{array}{c}\text { B } \\
(n=3)\end{array}$} \\
\hline & $\begin{array}{l}\text { MRR } \\
(n=3)\end{array}$ & $\begin{array}{c}\mathbf{H} \\
(n=4)\end{array}$ & $\begin{array}{c}\mathrm{L} \\
(n=4)\end{array}$ & $\begin{array}{c}\mathbf{M} \\
(n=5)\end{array}$ & $\begin{array}{c}\text { Sm } \\
(n=5)\end{array}$ & & & & \\
\hline $\mathrm{pH}$ & 8.0 & 8.4 & 8.6 & 8.2 & 8.0 & 8.2 & 7.5 & 7.3 & 5.6 \\
\hline Mineralization, $\mathrm{mg} / \mathrm{L}$ & 144 & 233 & 87 & 73 & 58 & 113 & 35 & 32 & 6.4 \\
\hline Solid particles, mg/L & 93 & 83 & 28 & 31 & 24 & 48 & 15 & 17 & 9.0 \\
\hline $\begin{array}{c}\text { Dust load, } \mathrm{mg} / \mathrm{m}^{2} \\
\text { per day }\end{array}$ & 133 & 102 & 35 & 41 & 30 & 62 & 20 & 21 & 9.0 \\
\hline $\begin{array}{l}\text { Snow cover } \\
\text { thickness, } \mathrm{cm}\end{array}$ & 50 & 42 & 46 & 45 & 42 & 45 & 45 & 45 & 61 \\
\hline Water supply, $\mathrm{L} / \mathrm{m}^{2}$ & 91 & 73 & 83 & 80 & 77 & 80 & 79 & 77 & 67 \\
\hline $\mathrm{Na}^{+}, \mu \mathrm{eq} / \mathrm{L}$ & 1126 & 2357 & 505 & 594 & 436 & 951 & 262 & 236 & 8 \\
\hline $\mathrm{K}^{+}, \mu \mathrm{eq} / \mathrm{L}$ & 9 & 25 & 14 & 9 & 11 & 14 & 16 & 28 & 1 \\
\hline $\mathrm{Mg}^{2+}, \mu \mathrm{eq} / \mathrm{L}$ & 17 & 20 & 38 & 12 & 12 & 19 & 9 & 19 & 4 \\
\hline $\mathrm{Ca}^{2+}, \mu \mathrm{eq} / \mathrm{L}$ & 1039 & 1459 & 707 & 498 & 394 & 773 & 226 & 178 & 69 \\
\hline $\mathrm{Cl}^{-}, \mu \mathrm{eq} / \mathrm{L}$ & 1400 & 3353 & 607 & 719 & 434 & 1229 & 278 & 240 & 7 \\
\hline $\mathrm{NO}_{3}{ }^{-}, \mu \mathrm{eq} / \mathrm{L}$ & 22 & 28 & 29 & 25 & 26 & 26 & 24 & 29 & 24 \\
\hline $\mathrm{SO}_{4}^{2-}, \mu \mathrm{eq} / \mathrm{L}$ & 92 & 104 & 79 & 63 & 82 & 83 & 70 & 59 & 15 \\
\hline $\mathrm{HCO}_{3}{ }^{-}, \mu \mathrm{eq} / \mathrm{L}$ & 678 & 374 & 550 & 305 & 310 & 420 & 141 & 134 & 38 \\
\hline
\end{tabular}

* Roads: H—highways, L-large, M-medium, Sm—small; R—average for roads; Y—yards with parking lots;

$\mathrm{B}-$ background; $n$-number of mixed samples.

$\mathrm{pH}$ value is an integral indicator of acidifying and alkalizing compounds' ratio and reflects the influence of these compounds on the carbonatic equilibrium. According to 2018 data, the $\mathrm{pH}$ value of contaminated snow meltwater in WAO ranged from 7.3 to 8.8 with an average of 8.1 ; that is, the alkalization of snow cover in the city is intensive and exceeds the background by $2.5 \mathrm{pH}$ units. The highest $\mathrm{pH}$ values 7.6-8.8 are common for roads; with an average $\mathrm{pH}$ of 8.2 , the alkalization of meltwater decreases in the following sequence of roads: large (8.6) $>$ highways (8.4) $>$ medium (8.2) > small and the MRR (8.0). The rising $\mathrm{pH}$ value of snow meltwater with an increase in traffic intensity was also recorded in Lahti, Finland [55]. The intensity of alkalization in WAO is lower in the yards of residential buildings with car parking lots-the average $\mathrm{pH}$ of snow meltwater is 7.4 with slight variations from 7.3 to 7.5. The $\mathrm{pH}$ of snow water in the territory of the MO MSU is 7.3, which is close to the mean value for residential zones. In Moscow, like most other cities, there is alkalinization of surface soil horizons $[29,30,64-66]$, road dust particles $[65,67,68]$, and bottom sediments of lakes and ponds [69]. Previous studies on Moscow soil water extract and the composition of salts in soils showed a significant increase in the amount of carbonates [29], as opposed to the background sod-podzolic soils that do not contain carbonates at all. This, together with results of research in other cities [70], indicates significant influence of carbonates on the soils' $\mathrm{pH}$ value. The sources of carbonaceous compounds in the urban environments, aside from natural—originated carbonate particles, are dust from construction and demolition activities, as well as road dust particles mainly related to tire wear, motor exhaust, and brake wear [71-73]. Thus, rather high $\mathrm{pH}$ values of snow 
meltwater are associated with partial dissolution of incoming urban soils and road dust particles on snow cover surface. It is known that partial dissolution of solid particles of various geneses increase the rainwater $\mathrm{pH}$ values [74]. Greater $\mathrm{pH}$ values of roadside snow meltwater sampled near large roads confirm the hypothesis of road dust particles being the most important alkalizing agent for the snow of WAO. The $\mathrm{pH}$ of road dust water extract for Moscow large roads varies from 6.9 to 8.1 and decreases in the yards [68]. An additional source of alkalizing agents in snow cover is marble chips, which is a commonly used DIS in Moscow [75]. On the contrary, chloride DISs can slightly reduce the $\mathrm{pH}$ of precipitation and snow due to the formation of gaseous $\mathrm{HCl}, \mathrm{ClNO}_{2}$, and $\mathrm{Cl}_{2}$ as a result of the reaction of $\mathrm{NaCl}$ with gaseous $\mathrm{HNO}_{3}, \mathrm{H}_{2} \mathrm{SO}_{4}, \mathrm{~N}_{2} \mathrm{O}_{5}$, and $\mathrm{ClONO}_{2}$ [76].

The intensive geochemical impact of transport and industrial facilities and the application of DISs led to a significant increase in the concentration of solid particles in snow cover (2-5-fold), the intensity of dust load (2-7-fold), and mineralization (5-18-fold), as well as to the change in the ionic composition of snow meltwater in WAO relative to the background. The mineralization of meltwater next to roads in the western part of Moscow averages $100 \mathrm{mg} / \mathrm{L}$, varying from 18 to $331 \mathrm{mg} / \mathrm{L}$; in the yards of residential buildings, it varies from 18 to $63 \mathrm{mg} / \mathrm{L}$ and amounts $32 \mathrm{mg} / \mathrm{L}$ in the territory of the MO MSU. In terms of the mineralization of snow meltwater, the roads of WAO form a following series: highways $(233 \mathrm{mg} / \mathrm{L})>\operatorname{MRR}(144)>$ large $(87)>$ medium $(73)>$ small $(58 \mathrm{mg} / \mathrm{L})$. In Moscow, the average annual concentrations of atmospheric $\mathrm{PM}_{10}$ in 2018 totaled 0.7 of the maximum permissible concentrations (that is, about $40 \mu \mathrm{g} / \mathrm{m}^{3}$ ); near highways, the concentration of $\mathrm{PM}_{10}$ was 1.4 times higher than inside residential areas [35]. At the same time, $\mathrm{PM}_{10}$ concentrations in the city decreased by an average of $3.7 \%$ annually in 2005-2014 [77]. Our data on snow cover pollution show an increase in the content of solid particles by almost four times in snow meltwater near roads compared to the yards of residential buildings with car parking lots, which indicates a significant contribution of particles larger than $\mathrm{PM}_{10}$ to atmospheric deposition, as well as the presence of an additional source of solid particles in snow, e.g., DISs. A sharp increase in the content of particulate matter in snow cover when using DISs was also found in other cities, for example, in Yekaterinburg (Russia); where the content of particulate matter in the snow cover of roads and footpaths is $4-5$ times higher than in the snow cover of lawns and car parking lots in the yards [21].

The ionic composition of snow meltwater near the Moscow Ring Road, the highways, and large and medium roads differs slightly. It is almost everywhere of calcium-sodium chloride type, which compares favorably with the results of long-term (1999-2019) studies of acidity and chemical composition of snow and rainfall in Moscow and Moscow Region [58,63,78]. Only at sampling points on the streets of Molodogvardeiskaya (point S16 in Figure 1) and Ryabinovaya (point S08) near the construction sites and industrial zones Severnoye Ochakovo and Yuzhnoye Ochakovo is the water of calcium-sodium bicarbonate-chloride type. Snow meltwater near small roads, at car parking lots in the yards of residential buildings, and on the territory of the MO MSU has the same composition with slightly higher proportion of bicarbonates, nitrates, sulfates, and calcium and lower proportion of chlorides and sodium, probably due to smaller amounts of DISs, which is also confirmed by low mineralization of meltwater on these territories as compared to other roads.

Water supply in the snow cover next to the roads is average $80 \mathrm{~L} / \mathrm{m}^{2}$, slightly decreasing in the yards $\left(79 \mathrm{~L} / \mathrm{m}^{2}\right)$ and the MO MSU $\left(77 \mathrm{~L} / \mathrm{m}^{2}\right)$. Water supplies in the background snow cover are lower and amounts to $67 \mathrm{~L} / \mathrm{m}^{2}$ as a result of partial snow blowing by the wind. Snow cover in the city is less susceptible to blowing due to higher density resulting from slightly higher air temperatures (heat island) and, accordingly, more frequent temperature transitions around $0{ }^{\circ} \mathrm{C}$ in March (during snow cover sampling period) and the earlier start of snow melting. 


\subsection{MMs Concentrations in Snow Cover}

\subsubsection{Dissolved Forms of MMs}

Average, minimum, and maximum concentrations of MMs forms in snow cover near roads, in the yards of residential buildings, near the MO MSU, and in the background area are given in Table 2. The value of contamination factor CF (Table 4) shows the excess of MMs forms' concentrations above the background level and, therefore, the level of snow cover contamination.

The maximum content of dissolved forms of most MMs is observed in roadside snow cover, because of vehicular impact; it gradually decreases in the yards and at the MO MSU down to minimum levels in snow cover of the background territory in the suburbs. The $C F$ factor varies quite a lot along the roads with different traffic intensities in WAO. The snow cover is most heavily contaminated with dissolved $\mathrm{Na}$, the $C F$ of which regularly declines as the road size decreases: from 280 near the highways, 134 near the MRR and 50-70 near large, medium and small roads, and down to 28-31 in the yards of residential buildings and at the MO MSU. The main source of dissolved Na is DISs; thus, dissolved $\mathrm{Ca}$ and $\mathrm{Sr}$ actively accumulate in snow cover too. Their CFS also decline as the road size decreases: from 14-23 at the MRR and highways to 6-10 on large, medium, and small roads, and down to 3-6 in the yards and at the MO MSU. High values of correlation coefficient $r$ for pairs $\mathrm{Na}-\mathrm{Cl}^{-}(0.99), \mathrm{Ca}-\mathrm{Cl}^{-}$ (0.87), and $\mathrm{Sr}_{-} \mathrm{Cl}^{-}$(0.94) indicate the entry of these metals with chloride-type DISs, applied frequently in Moscow. This is confirmed by the studies of snow cover composition in the southwestern part of Moscow, where the use of DISs contributed to a sharp increase in $\mathrm{Na}, \mathrm{Ca}$, and $\mathrm{K}$ concentrations [39].

Motor vehicle emissions could be an additional source of Na. Petrol Euro 3, 4, 5 and diesel Euro 3, 4 vehicles emit up to $1310 \mu \mathrm{g}$ Na per $1 \mathrm{~km}$ [80]. Strontium is probably an impurity in DISs, since this metal is often a part of calcium compounds. Concentrations of dissolved forms of MMs in snow cover depend on the intensity of transport impact; they are also associated with different amounts of DISs applied on different roads. For example, the concentrations of $\mathrm{Na}$ in snow of Novi $\mathrm{Sad}$ (Serbia), those of $\mathrm{Cu}, \mathrm{Fe}, \mathrm{Zn}$, and $\mathrm{Pb}$ in snow of Beijing (China), and those of $\mathrm{Al}, \mathrm{Co}, \mathrm{Cr}, \mathrm{Cu}, \mathrm{Mn}$, and $\mathrm{Ni}$ in snow of Lahti (Finland) increase with larger road size, while the concentrations of $\mathrm{Zn}$ in Novi Sad and $\mathrm{Cl}^{-}$in Beijing decrease [4,12,55].

In the western part of Moscow, several MMs showed local maxima of concentrations in the yards and at the MO MSU, where large areas are occupied by parking lots. Thus, high levels of dissolved $\mathrm{K}$ are probably due to the active fuel combustion during car engine idling; this is confirmed by the value of $r=0.57$ between the content of dissolved $\mathrm{K}$ and $\mathrm{NO}_{3}{ }^{-}$. It is known that $\mathrm{NO}_{3}{ }^{-}$is produced by fuel burning, in particular by motor transport [81], amounting up to $2280 \mu \mathrm{g} \mathrm{NO}{ }_{3}{ }^{-}$per $1 \mathrm{~km} \mathrm{[80].}$ Even larger amounts of water-soluble $\mathrm{NO}_{3}{ }^{-}$are released when burning diesel fuel [82]. Therefore, $\mathrm{K}$ is used as an indicator of vehicle emissions when studying the composition of aerosols $[83,84]$. It occurs in unleaded gasoline [85] and comes abundantly with road dust, especially in tunnels, and with direct tailpipe emissions of cars $[80,86,87]$. Fuel burning also causes the release of V into the environment $[88,89]$, and therefore its concentrations are high in the snow cover near parking lots. In general, MMs emissions over cruise conditions are substantially different from the emissions over a transient cycle or while idling [90]. 
Table 2. Concentrations of dissolved and suspended forms of MMs in snow cover near roads, at car parking lots in the yards of residential buildings, at the MO MSU and in the background area in March 2018, $\mu \mathrm{g} / \mathrm{L}$.

\begin{tabular}{|c|c|c|c|c|c|c|c|c|c|c|c|c|c|c|c|c|c|c|c|c|}
\hline \multirow{3}{*}{ MMs } & \multicolumn{10}{|c|}{ Dissolved Forms } & \multicolumn{10}{|c|}{ Suspended Forms } \\
\hline & \multicolumn{3}{|c|}{ Roads $(n=21)$} & \multicolumn{3}{|c|}{ Yards $(n=4)$} & \multirow{2}{*}{$\begin{array}{c}\text { MO } \\
\text { MSU }(n=1) \\
\text { Mean }\end{array}$} & \multicolumn{3}{|c|}{ Background $(n=3)$} & \multicolumn{3}{|c|}{ Roads $(n=21)$} & \multicolumn{3}{|c|}{ Yards $(n=4)$} & \multirow{2}{*}{$\begin{array}{c}\text { MO } \\
\text { MSU }(n=1) \\
\text { Mean }\end{array}$} & \multicolumn{3}{|c|}{ Background $(n=3)$} \\
\hline & Mean & Min. & Max. & Mean & Min. & Max. & & Mean & Min. & Max. & Mean & Min. & Max. & Mean & Min. & Max. & & Mean & Min. & Max. \\
\hline $\mathrm{Na}$ & 21870 & 2830 & 85900 & 6022 & 1960 & 15620 & 5430 & 193 & 170 & 210 & 932 & 69 & 10907 & 103 & 54 & 172 & 109 & 24 & 17 & 38 \\
\hline $\mathrm{Mg}$ & 233 & 100 & 840 & 107 & 100 & 120 & 230 & $50 *$ & $50 *$ & $50 *$ & 1110 & 102 & 12610 & 145 & 83 & 228 & 148 & 28 & 22 & 39 \\
\hline $\mathrm{Al}$ & 75 & 31 & 227 & 65 & 39 & 111 & 53 & 58 & 47 & 69 & 4216 & 351 & 48798 & 526 & 299 & 822 & 638 & 165 & 103 & 270 \\
\hline $\mathrm{K}$ & 531 & 100 & 1210 & 617 & 260 & 950 & 1110 & $50 *$ & $50 *$ & $50 *$ & 836 & 106 & 8660 & 157 & 85 & 242 & 164 & 61 & 36 & 108 \\
\hline $\mathrm{Ca}$ & 15498 & 2820 & 46160 & 4535 & 2800 & 5800 & 3570 & 1387 & 1230 & 1690 & 4010 & 251 & 44960 & 462 & 227 & 778 & 478 & 50 & 30 & 81 \\
\hline $\mathrm{Ti}$ & 2.0 & $0.3 *$ & 13 & 0.85 & 0.55 & 1.1 & 1.0 & 1.1 & 1.0 & 1.2 & 345 & 30 & 3900 & 48 & 29 & 76 & 45 & 8.3 & 1.9 & 18 \\
\hline $\mathrm{V}$ & 0.92 & $0.2 *$ & 2.9 & 0.76 & $0.2 *$ & 1.7 & 1.1 & $0.2 *$ & $0.2 *$ & $0.2 *$ & 12 & 1.1 & 135 & 2.1 & 1.4 & 2.7 & 2.8 & 0.27 & 0.16 & 0.45 \\
\hline $\mathrm{Cr}$ & 0.66 & $0.5^{*}$ & 3.9 & $0.5 *$ & 0.5 * & $0.5 *$ & $0.5 *$ & $0.5^{*}$ & 0.5 * & 0.5 * & 11 & 0.44 & 140 & 1.1 & 0.59 & 1.6 & 8.8 & 0.71 & 0.53 & 1.0 \\
\hline $\mathrm{Mn}$ & 11 & 3.8 & 84 & 12 & 3.2 & 34 & 3.9 & 4.5 & 3.2 & 6.2 & 55 & 5.5 & 603 & 8.4 & 4.5 & 14 & 8.1 & 3.0 & 1.2 & 5.8 \\
\hline $\mathrm{Fe}$ & 93 & 25 & 440 & 68 & 37 & 93 & 46 & 49 & 43 & 56 & 3848 & 452 & 39098 & 680 & 383 & 1036 & 678 & 139 & 94 & 218 \\
\hline Co & 0.28 & 0.12 & 1.0 & 0.18 & 0.1 & 0.3 & 0.11 & 0.071 & 0.054 & 0.091 & 1.6 & 0.13 & 19 & 0.19 & 0.11 & 0.31 & 0.22 & 0.037 & 0.02 & 0.058 \\
\hline $\mathrm{Ni}$ & 4.6 & $1.7^{*}$ & 28 & $1.7^{*}$ & $1.7 *$ & $1.7 *$ & 3.6 & $1.7^{*}$ & $1.7^{*}$ & $1.7^{*}$ & 6.1 & 0.51 & 76 & 1.1 & 0.67 & 1.4 & 1.7 & 0.45 & 0.3 & 0.67 \\
\hline $\mathrm{Cu}$ & 5.2 & 2.5 & 13 & 4.1 & 2.8 & 4.9 & 4.9 & 2.8 & 2.5 & 3.1 & 17 & 2.1 & 121 & 3.8 & 2.5 & 4.7 & 6.1 & 0.65 & 0.58 & 0.7 \\
\hline $\mathrm{Zn}$ & 16 & 8.7 & 29 & 18 & 12 & 23 & 24 & 22 & 15 & 31 & 33 & 3.9 & 311 & 6.9 & 3.7 & 9.2 & 18 & 1.1 & 0.63 & 1.7 \\
\hline As & $0.05 *$ & $0.05^{*}$ & $0.05 *$ & $0.05 *$ & $0.05 *$ & $0.05 *$ & $0.05^{*}$ & $0.05^{*}$ & $0.05 *$ & $0.05^{*}$ & 0.27 & 0.013 & 2.6 & 0.077 & 0.014 & 0.11 & 0.12 & 0.013 & 0.01 & 0.016 \\
\hline $\mathrm{Rb}$ & 0.43 & 0.22 & 0.88 & 0.35 & 0.25 & 0.52 & 0.34 & 0.19 & 0.17 & 0.23 & 3.1 & 0.42 & 32 & 0.56 & 0.33 & 0.81 & 0.60 & 0.2 & 0.12 & 0.38 \\
\hline $\mathrm{Sr}$ & 14 & 4.9 & 40 & 7.2 & 5.2 & 11 & 7.0 & 1.2 & 1.0 & 1.3 & 17 & 1.6 & 191 & 2.7 & 1.8 & 4.1 & 4.4 & 0.41 & 0.23 & 0.74 \\
\hline Mo & 0.26 & $\underset{*}{0.025}$ & 3.4 & 0.071 & $\begin{array}{c}0.025 \\
*\end{array}$ & 0.16 & $0.025^{*}$ & $\underset{*}{0.025}$ & $\underset{*}{0.025}$ & $\underset{*}{0.025}$ & 0.71 & 0.083 & 7.0 & 0.17 & 0.1 & 0.21 & 0.25 & 0.02 & 0.015 & 0.025 \\
\hline $\mathrm{Cd}$ & 0.068 & 0.019 & 0.61 & 0.064 & 0.028 & 0.12 & 0.061 & 0.033 & 0.017 & 0.047 & 0.053 & 0.008 & 0.42 & 0.018 & 0.009 & 0.025 & 0.025 & 0.006 & $\begin{array}{c}0.001 \\
*\end{array}$ & 0.012 \\
\hline Sn & 0.015 & $\underset{*}{0.005}$ & 0.21 & 0.012 & $\begin{array}{c}0.005 \\
*\end{array}$ & 0.033 & $0.005^{*}$ & $\begin{array}{c}0.005 \\
*\end{array}$ & $\underset{*}{0.005}$ & $\underset{*}{0.005}$ & 1.3 & 0.35 & 9.6 & 0.59 & 0.38 & 0.75 & 0.56 & 0.063 & 0.04 * & 0.098 \\
\hline $\mathrm{Sb}$ & 0.38 & 0.1 & 4.0 & 0.12 & 0.095 & 0.16 & 0.12 & 0.068 & 0.063 & 0.074 & 0.79 & 0.11 & 8.0 & 0.21 & 0.16 & 0.25 & 0.26 & 0.029 & 0.022 & 0.044 \\
\hline $\mathrm{Ba}$ & 9.2 & 4.2 & 31 & 6.7 & 4.1 & 8.6 & 7.7 & 2.7 & 2.1 & 3.3 & 34 & 4.9 & 341 & 7.5 & 5.8 & 9.9 & 9.3 & 1.7 & 0.95 & 3.2 \\
\hline $\mathrm{W}$ & 0.11 & $0.02 *$ & 0.88 & $0.02 *$ & $0.02 *$ & $0.02 *$ & $0.02 *$ & $0.02 *$ & $0.02 *$ & $0.02 *$ & 2.6 & 0.25 & 28 & 0.33 & 0.19 & 0.47 & 0.27 & 0.045 & $\begin{array}{c}0.025 \\
*\end{array}$ & 0.068 \\
\hline $\mathrm{Pb}$ & 0.35 & 0.13 & 1.8 & 0.28 & 0.18 & 0.44 & 0.54 & 0.70 & 0.50 & 0.83 & 5.0 & 0.46 & 38 & 1.8 & 1.5 & 2.0 & 8.6 & 0.84 & 0.67 & 1.0 \\
\hline $\mathrm{Bi}$ & 0.003 & $\begin{array}{c}0.001 \\
*\end{array}$ & 0.029 & 0.002 & $\begin{array}{c}0.001 \\
*\end{array}$ & 0.006 & 0.001 * & $\begin{array}{c}0.001 \\
*\end{array}$ & $\underset{*}{0.001}$ & $\underset{*}{0.001}$ & 0.094 & 0.023 & 0.66 & 0.035 & 0.031 & 0.036 & 0.047 & 0.011 & 0.007 & 0.02 \\
\hline
\end{tabular}

Notes. * Concentrations below detection limits were assigned a value equal to a half of it [79]. MMs are listed in the order of increasing numbers in Mendeleev's Periodic Table. 
Table 3. Accumulation of dissolved and suspended MMs forms in snow cover of WAO.

\begin{tabular}{|c|c|c|c|c|c|c|c|}
\hline \multirow{2}{*}{\multicolumn{2}{|c|}{ Object (Number of Mixed Samples) }} & \multicolumn{5}{|c|}{ Values of Contamination Factor $C F$} & \multirow{3}{*}{$\begin{array}{r}\text { TCF } \\
194\end{array}$} \\
\hline & & $>50$ & $25-50$ & $10-25$ & 5-10 & $3-5$ & \\
\hline \multirow[b]{2}{*}{$\operatorname{MRR}(n=3)$} & DS & $\mathrm{Na}_{134}$ & - & $\mathrm{Ca}_{15} \mathrm{Sr}_{14}$ & $\mathrm{~W}_{7} \mathrm{~K}_{7} \mathrm{Co}_{5}$ & $\mathrm{Mo}_{4} \mathrm{Mg}_{4} \mathrm{Ba}_{4} \mathrm{~V}_{3}$ & \\
\hline & $S P$ & $\begin{array}{c}\mathrm{Ca}_{385} \mathrm{~W}_{258} \mathrm{Co}_{219} \mathrm{Ti}_{203} \mathrm{Mg}_{1999} \mathrm{Sr}_{198} \mathrm{Na}_{194} \\
\mathrm{Mo}_{141} \mathrm{Al}_{128} \mathrm{Fe}_{1222} \mathrm{Zn}_{120} \mathrm{Sb}_{113} \mathrm{Mn}_{88} \mathrm{As}_{86} \\
\mathrm{Ba}_{85} \mathrm{Cu}_{78} \mathrm{Cr}_{78} \mathrm{Ni}_{66} \mathrm{Rb}_{66} \mathrm{Sn}_{63} \mathrm{~K}_{60}\end{array}$ & $\mathrm{Cd}_{31} \mathrm{Bi}_{25}$ & $\mathrm{~Pb}_{19}$ & - & 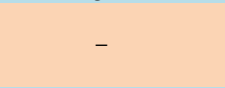 & 3212 \\
\hline \multirow{2}{*}{ Highways $(n=4)$} & DS & $\mathrm{Na}_{280}$ & - & $\mathrm{Sr}_{23} \mathrm{Ca}_{21} \mathrm{~K}_{20} \mathrm{~W}_{19} \mathrm{Sn}_{11}$ & $\mathrm{Bi}_{8} \mathrm{Co}_{6} \mathrm{Mo}_{6} \mathrm{Mg}_{5} \mathrm{Ni}_{5} \mathrm{~V}_{5}$ & $\mathrm{Ba}_{4} \mathrm{Sb}_{3} \mathrm{Fe}_{3} \mathrm{Ti}_{3}$ & 414 \\
\hline & $S P$ & $\mathrm{Ca}_{64}$ & $\begin{array}{l}\mathrm{W}_{47} \mathrm{Co}_{31} \mathrm{Ti}_{31} \mathrm{Sr}_{29} \\
\mathrm{~V}_{29} \mathrm{Mg}_{28} \mathrm{Na}_{27}\end{array}$ & $\begin{array}{l}\mathrm{Zn}_{24} \mathrm{Moo}_{22} \mathrm{Fe}_{20} \mathrm{Sn}_{17} \mathrm{Al}_{17} \mathrm{Sb}_{16} \\
\mathrm{Cu}_{15} \mathrm{Ba}_{14} \mathrm{As}_{13} \mathrm{Mn}_{13} \mathrm{Rb}_{11} \mathrm{~K}_{10}\end{array}$ & $\mathrm{Cd}_{7} \mathrm{Bi}_{6} \mathrm{Ni}_{6} \mathrm{Cr}_{6}$ & $\mathrm{~Pb}_{4}$ & 481 \\
\hline \multirow{2}{*}{ Large roads $(n=4)$} & DS & $\mathrm{Na}_{60}$ & $\mathrm{Mo}_{36}$ & $\mathrm{Sb}_{17} \mathrm{~K}_{11} \mathrm{Ca}_{10}$ & $\mathrm{Sr}_{9} \mathrm{Mg}_{9}$ & $\mathrm{~V}_{4} \mathrm{Co}_{3}$ & 156 \\
\hline & $S P$ & - & - & $\begin{array}{l}\mathrm{Ca}_{24} \mathrm{~W}_{21} \mathrm{Cu}_{17} \mathrm{Moo}_{16} \mathrm{Zn}_{14} \mathrm{Sr}_{13} \mathrm{Co}_{12} \\
\mathrm{Sn}_{12} \mathrm{Sb}_{11} \mathrm{Mg}_{11} \mathrm{~V}_{11} \mathrm{Ti}_{10} \mathrm{As}_{10} \mathrm{Na}_{10}\end{array}$ & $\begin{array}{l}\mathrm{Fe}_{9} \mathrm{Ba}_{8} \mathrm{Al}_{7} \mathrm{Rb}_{6} \mathrm{Mn}_{6} \\
\mathrm{Bi}_{6} \mathrm{Cd}_{5} \mathrm{~K}_{5} \mathrm{Ni}_{5} \mathrm{~Pb}_{5}\end{array}$ & $\mathrm{Cr}_{4}$ & 235 \\
\hline \multirow{2}{*}{ Medium roads $(n=5)$} & DS & $\mathrm{Na}_{71}$ & - & 120 - & $\mathrm{Sr}_{9} \mathrm{Ca}_{7} \mathrm{~K}_{7} \mathrm{Cd}_{6} \mathrm{Mn}_{5} \mathrm{Co}_{5}$ & $\mathrm{~V}_{4} \mathrm{Mg}_{3} \mathrm{Mo}_{3}$ & 116 \\
\hline & $S P$ & & & $\begin{array}{c}\mathrm{Cu}_{22} \mathrm{Ca}_{21} \mathrm{~W}_{19} \mathrm{Mo}_{18} \mathrm{Sn}_{14} \mathrm{Sb}_{13} \mathrm{~V}_{13} \\
\mathrm{Sr}_{13} \mathrm{Zn}_{12} \mathrm{Ti}_{11} \mathrm{Mg}_{11} \mathrm{Co}_{11} \mathrm{As}_{11} \mathrm{Na}_{10} \mathrm{Fe}_{10}\end{array}$ & $\mathrm{Ba}_{8} \mathrm{Al}_{7} \mathrm{Rb}_{6} \mathrm{~K}_{6} \mathrm{Mn}_{6} \mathrm{Bi}_{5}$ & $\mathrm{Cd}_{4} \mathrm{Ni}_{4} \mathrm{Cr}_{4} \mathrm{~Pb}_{4}$ & 240 \\
\hline \multirow{2}{*}{ Small roads $(n=5)$} & DS & $\mathrm{Na}_{52}$ & - & - & $\mathrm{K}_{9} \mathrm{Sr}_{7} \mathrm{Ca}_{6} \mathrm{~V}_{6} \mathrm{Mo}_{5}$ & $\mathrm{Sb}_{4} \mathrm{Ba}_{4} \mathrm{Ni}_{4} \mathrm{Mg}_{3}$ & 98 \\
\hline & $S P$ & - & - & $\begin{array}{l}\mathrm{Mo}_{17} \mathrm{~V}_{15} \mathrm{Ca}_{13} \mathrm{Sn}_{12} \mathrm{~W}_{12} \\
\mathrm{Cu}_{12} \mathrm{Sb}_{11} \mathrm{As}_{10} \mathrm{Zn}_{10} \mathrm{Fe}_{10}\end{array}$ & $\begin{array}{c}\mathrm{Sr}_{9} \mathrm{Cog}_{9} \mathrm{Ti}_{8} \mathrm{Mgg}_{7} \mathrm{Na}_{6} \\
\mathrm{Ba}_{6} \mathrm{Al}_{5} \mathrm{Mn}_{5} \mathrm{Bi}_{5}\end{array}$ & $\mathrm{Cd}_{4} \mathrm{Ni}_{4} \mathrm{Rb}_{4} \mathrm{~K}_{4} \mathrm{~Pb}_{3} \mathrm{Cr}_{5}$ & 179 \\
\hline \multirow{2}{*}{ Average for roads $(n=21)$} & DS & $\mathrm{Na}_{113}$ & - & $\mathrm{Sr}_{12} \mathrm{Ca}_{11} \mathrm{~K}_{11} \mathrm{Mo}_{10}$ & $\mathrm{Sb}_{6} \mathrm{~W}_{6} \mathrm{Mg}_{5} \mathrm{~V}_{5}$ & $\mathrm{Co}_{4} \mathrm{Sn}_{3} \mathrm{Ba}_{3}$ & 187 \\
\hline & $S P$ & $\mathrm{Ca}_{80} \mathrm{~W}_{57}$ & $\begin{array}{l}\mathrm{Co}_{44} \mathrm{~V}_{44} \mathrm{Sr}_{44} \mathrm{Ti}_{41} \mathrm{Mg}_{40} \mathrm{Na}_{39} \\
\mathrm{M}_{3} \mathrm{Na}_{4} \mathrm{Zn}_{3} \mathrm{Fe}_{28} \mathrm{Sb}_{27} \mathrm{Cu}_{25}\end{array}$ & $\begin{array}{c}\mathrm{As}_{22} \mathrm{Sn}_{21} \mathrm{Ba}_{20} \mathrm{Mn}_{19} \\
\mathrm{Al}_{2} \mathrm{Rb}_{1} \mathrm{Cr}_{10} \mathrm{~K}_{14} \mathrm{Ni}_{14}\end{array}$ & $\mathrm{Cd}_{9} \mathrm{Bi}_{8} \mathrm{~Pb}_{6}$ & - & 695 \\
\hline \multirow{2}{*}{ Yards with car parking lots $(n=4)$} & DS & $\mathrm{Na}_{31}$ & - & $\mathrm{K}_{12}$ & $\mathrm{Sr}_{6}$ & $\mathrm{~V}_{4} \mathrm{Ca}_{3}$ & 66 \\
\hline & $S P$ & - & - & - & $\begin{array}{l}\mathrm{Sn}_{9} \mathrm{Ca}_{9} \mathrm{Mo}_{8} \mathrm{~V}_{8} \mathrm{Sb}_{7} \mathrm{~W}_{7} \mathrm{Sr}_{6} \\
\mathrm{Zn}_{6} \mathrm{As}_{6} \mathrm{Ti}_{6} \mathrm{Cu}_{6} \mathrm{Co}_{5} \mathrm{Mg}_{5} \mathrm{Fe}_{5}\end{array}$ & $\mathrm{Ba}_{4} \mathrm{Na}_{4} \mathrm{Al}_{3} \mathrm{Cd}_{3} \mathrm{Bi}_{3}$ & 103 \\
\hline \multirow{2}{*}{$\operatorname{MO} \operatorname{MSU}(n=1)$} & DS & $\mathrm{Na}_{28}$ & - & $\mathrm{K}_{22}$ & $\mathrm{~V}_{6} \mathrm{Sr}_{6} \mathrm{Mg}_{5}$ & - & 71 \\
\hline & $S P$ & - & - & $\begin{array}{c}\mathrm{Zn}_{16} \mathrm{Mo}_{13} \mathrm{Cr}_{12} \\
\mathrm{Sr}_{11} \mathrm{~V}_{10} \mathrm{~Pb}_{10} \mathrm{Ca}_{10}\end{array}$ & $\begin{array}{l}\mathrm{Cu}_{9} \mathrm{As}_{9} \mathrm{Sn}_{9} \mathrm{Sb}_{9} \mathrm{~W}_{6} \\
\mathrm{Co}_{6} \mathrm{Ba}_{5} \mathrm{Ti}_{5} \mathrm{Mg}_{5} \mathrm{Fe}_{5} \mathrm{Na}_{5}\end{array}$ & $\mathrm{Cd}_{4} \mathrm{Bi}_{4} \mathrm{Al}_{4} \mathrm{Ni}_{4}$ & 156 \\
\hline
\end{tabular}

Notes. The CF value of each element is written in the subscript. DS-dissolved (blue background), $S P$-suspended (orange background) forms. 
Besides the above-mentioned $\mathrm{Na}, \mathrm{Ca}, \mathrm{Sr}, \mathrm{K}$, and $\mathrm{V}$ due to the transport impact, the snow cover near all types of roads is highly polluted $(C F>3)$ with dissolved Mo and $\mathrm{Mg}$, with $\mathrm{W}$, Co, and Ba near the MRR, with $\mathrm{W}, \mathrm{Sn}, \mathrm{Bi}, \mathrm{Co}, \mathrm{Ni}, \mathrm{Ba}, \mathrm{Sb}, \mathrm{Fe}$, and Ti near highways, with $\mathrm{Sb}$ and $\mathrm{Co}$ near large roads, with $\mathrm{Cd}, \mathrm{Mn}$, and $\mathrm{Co}$ near medium roads, and with $\mathrm{Sb}, \mathrm{Ba}$, and $\mathrm{Ni}$ along small roads. The possible source of these MMs could be non-exhaust vehicle emissions [91-94], which is supported by the data on the intensive enrichment of Moscow road dust and especially its fractions $\mathrm{PM}_{1}$ and $\mathrm{PM}_{1-10}$ with $\mathrm{Sb}$, $\mathrm{W}, \mathrm{Sn}, \mathrm{Bi}$, and $\mathrm{Cd}[67,95,96]$, and nanoscale particles of road dust enriched with $\mathrm{Pb}, \mathrm{Cu}, \mathrm{Zn}, \mathrm{Ni}, \mathrm{Cd}, \mathrm{Cr}$, $\mathrm{Co}$, and Sn [97]. Therefore, the highest CF values for many of these MMs, in particular W and Sn, are characteristic of snow cover along the MRR and highways. High levels of dissolved $\mathrm{Na}, \mathrm{K}, \mathrm{Mg}, \mathrm{Fe}, \mathrm{Al}$, $\mathrm{Zn}, \mathrm{Sr}, \mathrm{Cu}$, and other MMs comparable to our data were also found in snow cover near the MRR in 2011 [48].

The most intensive accumulation of dissolved $\mathrm{Mo}$ and $\mathrm{Sb}$ in the western part of Moscow was observed in snow cover along large roads. Mo and $\mathrm{Sb}$ probably come with emissions from heat and power station No. 25 and other thermal power plants in WAO, as indicated by increased $r$ coefficients in pairs Mo-Sb (0.99), $\mathrm{Mo}_{-} \mathrm{SO}_{4}{ }^{2-}(0.48)$, and $\mathrm{Sb}_{-} \mathrm{SO}_{4}{ }^{2-}(0.45)$. During long and severe frosts, fuel oil is used as an additional fuel for power plants along with natural gas, thus contributing to higher $\mathrm{SO}_{2}$ emissions [77] and increasing $\mathrm{SO}_{4}{ }^{2-}$ concentrations in snow cover. The accumulation of $\mathrm{Mo}$ and $\mathrm{Sb}$ in snow cover is also characteristic of the eastern part of Moscow, where these elements are actively emitted by heat and power stations, as well as by metalworking, mechanical engineering, and petrochemical enterprises [46].

The MO MSU and the background territory are characterized by higher concentrations of dissolved $\mathrm{Zn}$ and $\mathrm{Pb}$ compared to snow cover along the roads and in the yards. The increased content of dissolved $\mathrm{Zn}$ in snow cover near the MO MSU compared to roadside snow cover was indicated earlier [40]. This is probably due to the regional transfer of pollutants from urbanized areas of the Moscow Oblast and the nearest regions, to the macro-regional transfer from Europe and global migration of pollutants. It is confirmed by the data on the accumulation of metals in the dust component of background snow cover near Zvenigorod in the western part of Moscow Oblast [46], in snow cover of the background regions of the Ryazan Meshchera [98], and the Polar Plateau in Antarctica [99]. High levels of Cd at the urban reference sites not polluted by traffic compared to snow near the roads were detected in Innsbruck, due to the input of metal from non-transport sources [23]. In Moscow, the snow cover composition at the MO MSU showed 2-3 times higher content of $\mathrm{Fe}, \mathrm{V}, \mathrm{Co}$, and $\mathrm{Ba}$; minor difference in content of $\mathrm{Al}, \mathrm{Mn}, \mathrm{Ni}, \mathrm{Cu}, \mathrm{As}$, and $\mathrm{Cd}$; and 2-3 times lower content of $\mathrm{Cr}, \mathrm{Zn}$, Sr, and Mo compared to the territory of the Botanical Garden next to the MO MSU [40].

Different rates of $C F$ value increment with increasing anthropogenic impact make it necessary to consider the behavior of all studied pollutants simultaneously and make an integral assessment of contamination. For this purpose, total contamination factor TCF of snow cover with dissolved and suspended MMs was calculated. The spatial distribution of TCF is shown in Figure 2. 


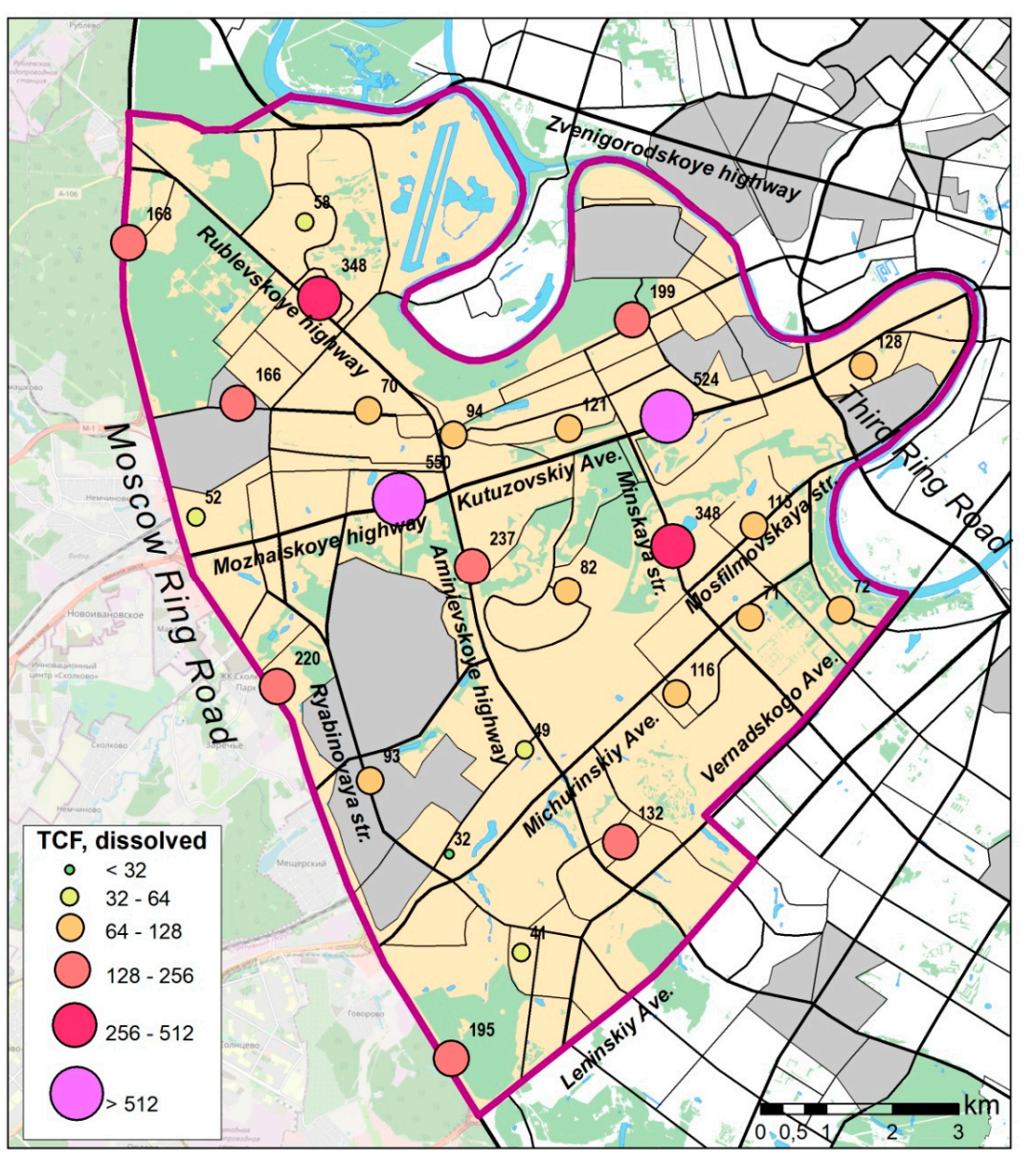

(a) Dissolved MMs

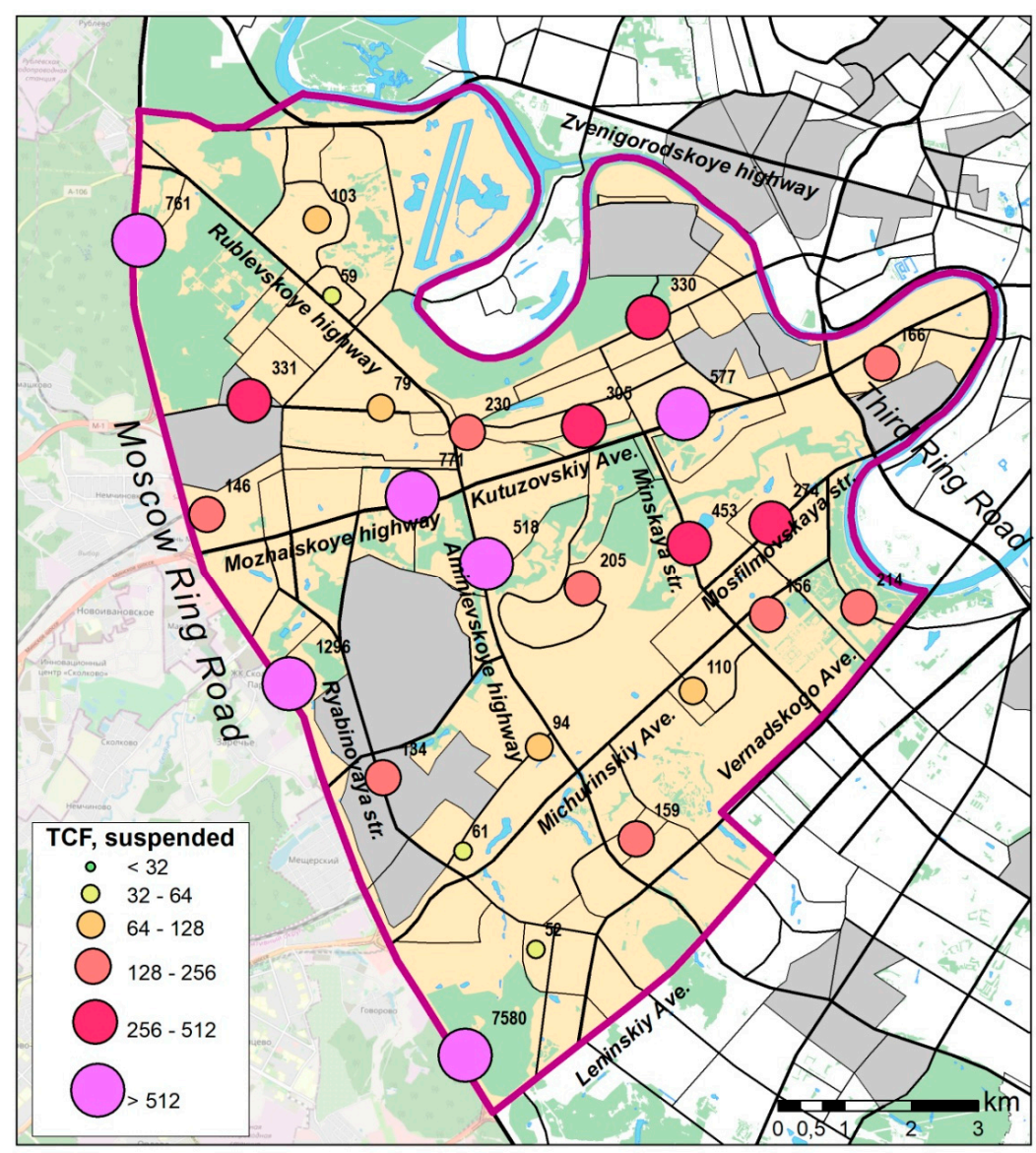

(b) Suspended MMs

Figure 2. Distribution of TCF values for dissolved and suspended MMs in the western part of Moscow. 
The maximum levels of MMs contamination in the dissolved phase of snow causing extremely dangerous environmental situations (TCF $>256$ ) are characteristic of the sections along Kutuzovskiy Avenue, Mozhaiskoye Highway (near the industrial zones Severnoye Ochakovo and Yuzhnoye Ochakovo), Rublevskoye Highway and Minskaya Street, mainly because of the application of DISs. Very high level of snow cover pollution and very dangerous environmental situations is characteristic of the MRR, Aminievskoye Highway, several medium (Molodogvardeiskaya St. near the Kuntsevo industrial zone and Bolshaya Filevskaya St. near the Fili and Western Port industrial zones) and small (Koshtoyantsa St., sampling point S20 in Figure 1) roads. Territories along almost all studied small roads and at the MO MSU have the high level of pollution (with TCF 64-128) and a dangerous environmental situation. The amount of applied DISs is lower in most yards, and the impact of transport decreases as well, but it does not completely disappear because of the presence of car parking lots. The decrease is also due to protective functions of buildings that act as barriers to air pollutant flows from the highways to the yards of residential buildings [100]. Buildings prevent the spread of emissions from vehicles, thus decreasing snow cover pollution to medium level (with TCF 32-64) and a moderately dangerous environmental situation.

\subsubsection{Suspended Forms of MMs}

The content of suspended forms of all MMs in roadside snow cover is higher than in snow cover of the yards, the MO MSU, and the background territory. Application of DISs on roads and further blowing of their particles by the wind leads to their inclusion into roadside snow. This accounts for the fact that the highest $C F$ values of $C a(385,64$, and 24 , respectively) were found in snow cover of the MRR, highways, and large roads, decreasing on medium roads, small roads, in yards, and at the MO MSU $(21,13,9$, and 10, respectively). Suspended forms of all MMs, except $\mathrm{K}, \mathrm{Mo}$, and $\mathrm{Sb}$, are accumulated much more intensively than dissolved ones, due to enrichment of the dust component of snow cover with MMs and the high content of solid particles in snow cover. Solid particles' input to the snow cover is due to precipitation from the atmosphere, DISs application on roads, blowing of road dust and soils particles from snow-free areas, and spraying of mud sediment from the surface of roadways during snow melting. Resuspended road dust is reported to be one of the most important sources of microparticles in the atmosphere; for example, in Bogota, it supplies about $23 \%$ of the mass of $\mathrm{PM}_{10}$ particles [101] and in the USA, more than a half of $\mathrm{PM}_{10}$ and about a quarter of $\mathrm{PM}_{2.5}$ particles [102]. In Paris, the contributions of road dust emissions were estimated to be $13 \%$ of atmospheric $\mathrm{PM}_{10}$, while the sum of vehicle exhaust and wear accounted for $47 \%$ of $\mathrm{PM}_{10}$ [103]. Moreover, for the north cities, the spraying of mud sediment from the surface of roadways is an essential source of suspended particles and MMs in roadside snow cover [21].

On large roads, dissolved $\mathrm{Mo}$ and $\mathrm{Sb}$ accumulate more intensively compared to its suspended forms, which is probably due to the increased $\mathrm{pH}$ of snow meltwater (an average of 8.6 on large roads, 8.0-8.4 on other roads). These elements are typical anionogenic elements and migrate well in alkaline conditions, so the higher $\mathrm{pH}$ values could contribute to the acceleration of their dissolution [104]. A positive correlation of dissolved Mo content with $\mathrm{pH}$ values of river water and snow was also found in the basins of rivers flowing into the Gulf of Bothnia [105].

Smaller roads have lower traffic intensity, resulting in a decrease of accumulation of suspended MMs forms. $\mathrm{Ca}, \mathrm{W}, \mathrm{Co}, \mathrm{Ti}, \mathrm{Mg}, \mathrm{Sr}, \mathrm{Na}, \mathrm{Mo}, \mathrm{Al}, \mathrm{Fe}, \mathrm{Zn}, \mathrm{Sb}, \mathrm{Mn}, \mathrm{As}, \mathrm{Ba}, \mathrm{Cu}, \mathrm{Cr}, \mathrm{Ni}, \mathrm{Rb}, \mathrm{Sn}$, and $\mathrm{K}$ are accumulated intensively $(C F>50)$ in snow cover near the MRR. The $C F$ decreases sharply for all MMs along the highways, reaching 64 for $\mathrm{Ca}, 27-47$ for $\mathrm{W}, \mathrm{Co}, \mathrm{Ti}, \mathrm{Sr}, \mathrm{V}, \mathrm{Mg}$, and $\mathrm{Na}$ and less than 25 for other MMs. Along large and medium roads, the $C F$ of $\mathrm{Ca}, \mathrm{W}, \mathrm{Cu}, \mathrm{Mo}, \mathrm{Zn}, \mathrm{Sr}, \mathrm{Co}, \mathrm{Sn}$, $\mathrm{Sb}, \mathrm{Mg}, \mathrm{V}, \mathrm{Ti}, \mathrm{As}, \mathrm{Na}, \mathrm{Cu}$, and Fe decrease to $10-25$, and to 5-17 near small roads. Higher content of solid particles in snow cover at the MO MSU leads to the increase in $C F$ values for $\mathrm{Zn}, \mathrm{Mo}, \mathrm{Cr}$, $\mathrm{Sr}, \mathrm{V}, \mathrm{Pb}$, and $\mathrm{Ca}$ up to 10-16, as compared with the yards where CF values of these MMs are 5-9. High levels of $\mathrm{Zn}$ at the MO MSU are probably due to the influence of transport, since car parking lots are located nearby, where intense accumulation of the metal is typical [106]. Our studies on 
the chemical composition of dust component in snow cover of the eastern industrial part of Moscow showed that the following MMs are the ones that accumulate most intensively (the $C F$ value is written in subscript): $\mathrm{Mo}_{19} \mathrm{Sb}_{4.9} \mathrm{As}_{4.6} \mathrm{~W}_{4.3} \mathrm{Sn}_{3.6} \mathrm{~V}_{2.1} \mathrm{Fe}_{2.1} \mathrm{Cr}_{2.0}$ [46]. However, foregoing data include areas with low levels of snow cover pollution, namely recreational and agricultural zones; therefore, $C F$ levels for MMs are lower than those obtained for the traffic zone in the western part of the city.

The TCF values of suspended MMs increase considerably and the levels of environmental hazard increase by one gradation at many points, as compared to the total pollution of snow cover with dissolved forms. The highest increase of TCF for suspended forms is at the MRR, where the extremely dangerous environmental situation and the maximum TCF values were found, ranging from 761 in the northern part of the study area (4.5 times higher than the TCF for dissolved MMs forms) to 1296 on the average (6 times higher) and 7580 in the southern part (39 times higher). In other territories, the growth of $T C F$ for suspended forms relative to the dissolved ones is less pronounced, reaching 1.2 to 3 times. The exception is Rublevskoye Highway, where the TCF is almost 6 times lower due to the low dust content in snow cover (12 mg/L compared to $102 \mathrm{mg} / \mathrm{L}$ near the MRR). The low dust content in snow cover could be attributed to the large distance of sampling point from the highway itself-there is both an alternate route and a car parking lot on the roadside, which separate the sampling point from the highway.

Extremely high snow cover pollution on the territory near the intersection of the MRR and Leninskiy Avenue, one of the busiest highways in Moscow, is probably the result of very intense MMs inflow with vehicle emissions (enormous numbers of cars and traffic congestions), as well as the blowing of contaminated road dust microparticles. An extremely dangerous situation (TCF $>256$ ) also occurs on Kutuzovskiy Avenue, Mozhaiskoye and Aminievskoye highways, and a number of large (Minskaya and Mosfilmovskaya streets) and medium (Molodogvardeiskaya and Bolshaya Filevskaya streets—sites S16 and S12 in Figure 1, respectively) roads. In the yards of residential buildings, snow cover pollution with suspended forms of MMs as compared to dissolved ones increases to the high level (TCF 64-128), and to very high level (TCF 128-256), and very dangerous environmental situation for small and some medium roads.

Thus, snow cover pollution on the roadside territories in the western part of Moscow is mainly due to particulate matter. It is enriched with $\mathrm{Ca}, \mathrm{W}, \mathrm{Co}, \mathrm{V}, \mathrm{Sr}, \mathrm{Ti}, \mathrm{Mg}, \mathrm{Na}, \mathrm{Mo}, \mathrm{Zn}, \mathrm{Fe}, \mathrm{Sb}$, and $\mathrm{Cu}$. The MMs content in suspension along the roads is on average 25 times or more above the background. $\mathrm{Na}, \mathrm{Sr}, \mathrm{Ca}, \mathrm{K}, \mathrm{Mo}, \mathrm{Sb}$, and $\mathrm{W}$ are the main dissolved pollutants; their content in the snow of certain areas of the WAO is six or more times above the background level. The spatial pattern of the total contamination factor TCF is characterized by the formation of common centers of abnormally high values for both dissolved and suspended MMs forms on the MRR, Kutuzovskiy Avenue, Rublevskoye, Mozhaiskoye, and Aminievskoye highways and some other streets. The anomalies appear due to the application of DISs, vehicle emissions, as well as the impact of enterprises in the adjacent industrial zones, such as Severnoye Ochakovo, Yuzhnoye Ochakovo, Kuntsevo, Fili, and Western Port.

\subsection{Partitioning of $M M s$}

Studying the ratio of MMs forms is important for predicting the pollutants' behavior during and after snowmelt, since the dissolved phase has a higher migratory ability. Therefore, the risk of contamination greatly depends on the $\mathrm{MMs}^{\prime}$ ability to transform from a non-dissolved phase to a dissolved one. To define the predominant phase of elements in snow, the share of their dissolved phase, or solubility $(\mathrm{Kz}, \%)$ was calculated: $\mathrm{Kz}=100 \% \cdot \mathrm{Cdis} /(\mathrm{Cdis}+\mathrm{Csus})$, where Cdis is the concentration of dissolved phase of MMs, $\mu \mathrm{g} / \mathrm{L}$; Csus is the concentration of suspended phase, $\mu \mathrm{g} / \mathrm{L}$.

Most MMs in snow cover of the background territory prevail in dissolved form: the proportion of dissolved forms of $\mathrm{Ca}, \mathrm{Zn}, \mathrm{Na}, \mathrm{Cd}, \mathrm{Ni}, \mathrm{As}, \mathrm{Cu}$, and $\mathrm{Sr}$ is more than $85 \% ; 60-70 \%$ for $\mathrm{Sb}, \mathrm{Co}, \mathrm{Mg}$, $\mathrm{Mn}$, and $\mathrm{Ba}$, and $52-56 \%$ for $\mathrm{Rb}$ and Mo (Figure 3). These MMs are most likely washed out from the atmosphere and could enter the snow cover during in-cloud processes, i.e., elements' sorption on snowflakes inside the cloud [107]. Another source is washing out from the atmosphere with an 
ultrafine $(<0.45 \mu \mathrm{m})$ fraction of aerosols, which passes through filters in the process of snow meltwater filtration in the laboratory. The predominance of dissolved forms of MMs could also be attributed to a slightly acidic reaction ( $\mathrm{pH}$ 5.6) of snow meltwater in background areas, as the cationogenic $\mathrm{Ca}, \mathrm{Zn}$, $\mathrm{Na}, \mathrm{Cd}, \mathrm{Ni}, \mathrm{Cu}, \mathrm{Sr}, \mathrm{Co}, \mathrm{Mg}$, and Ba could be easily transferred from insoluble to soluble form in acidic waters $[104,108,109]$.

Other MMs are found predominately in suspended forms, which accounts for $80-90 \%$ of $\mathrm{Sn}$ and Bi, $60-80 \%$ of $\mathrm{Ti}, \mathrm{Al}, \mathrm{Fe}$, and $\mathrm{W}$, and $50-60 \%$ of $\mathrm{Pb}, \mathrm{V}, \mathrm{Cr}$, and $\mathrm{K}$. An increase in the proportion of suspended forms of MMs is related to the washout of the solid aerosol particles in the atmospheric surface layer by below-cloud scavenging processes [107]. In the background area, most of these MMs enter the atmosphere with relatively large soil particles blown from snow-free surfaces, thus contributing to higher proportion of suspended MMs forms. Thin snow cover, strong wind, and the absence of woody vegetation could significantly increase the soil particles supply to the roadside snow. Regional transport of contaminated atmospheric aerosol particles of different sizes also contributes to the higher proportion of suspended MMs forms. For example, in Northern China, $\mathrm{Al}$ and $\mathrm{Fe}$ in precipitation are mainly associated with large particles and $\mathrm{Pb}$ with thin ones, while $\mathrm{K}, \mathrm{V}$, and $\mathrm{Cr}$ have a bimodal distribution with peak concentrations within particle size intervals of 0.43-0.65 and 4.7-5.8 $\mu \mathrm{m}$ [110].

In urban areas, mass deposition of solid particles from the atmosphere and the application of DISs on roads with their subsequent blowing out and re-depositing on the surface of roadside snow cover significantly increase the role of suspended MMs forms. This is most pronounced in snow cover along roads (Figure 3), where the proportion of suspended forms is above $90 \%$ for $\mathrm{Sn}, \mathrm{Ti}, \mathrm{Bi}, \mathrm{Al}, \mathrm{W}$, and $\mathrm{Fe}$, 80-90\% for $\mathrm{Pb}, \mathrm{V}$, and $\mathrm{Cr}, 50-80 \%$ for $\mathrm{Rb}, \mathrm{Mo}, \mathrm{Mn}, \mathrm{As}, \mathrm{Co}, \mathrm{Cu}, \mathrm{Ba}, \mathrm{Sb}, \mathrm{Mg}$, and $\mathrm{Zn}$. The dissolved phase prevails for $\mathrm{K}, \mathrm{Ni}, \mathrm{Cd}$, and $\mathrm{Sr}$ (it accounts for $50-65 \%$ ), as well as for $\mathrm{Ca}(87 \%)$ and $\mathrm{Na}(97 \%)$.

The effect of dust deposition on the increasing proportion of suspended forms of MMs is confirmed by the high significant negative coefficients of rank correlation $r_{s}$ between the dust load and the proportion of dissolved forms for almost all MMs: $r_{s}$ are less than -0.67 for all MMs, except $\mathrm{K}$ $(-0.57), \mathrm{Sb}(-0.56), \mathrm{Ni}(-0.41)$, and insignificant for $\mathrm{Mo}, \mathrm{W}$, and $\mathrm{Na}$. Insignificant correlation between Mo and W solubility and dust load is due to numerous points with concentrations below the detection limit, for these elements. Weak Na solubility correlation with amount of dust particles is due to $\mathrm{Na}$ input mainly with DISs and their subsequent rapid dissolution, providing for just little effect on the dust load. High positive $r_{s}$ between the concentrations of $\mathrm{Cl}^{-}$in meltwater and the proportion of suspended forms of all MMs $\left(r_{s}=0.49-0.75\right)$, except $\mathrm{Sr}(0.44), \mathrm{Ca}(0.40), \mathrm{K}, \mathrm{Ni}, \mathrm{Mo}, \mathrm{W}(0.15-0.34)$, and $\mathrm{Na}(-0.28)$ indicate the presence of MMs as slightly soluble impurities in chloride DISs. High proportion of suspended MMs in snow cover of the WAO could be also explained by the change of subacidic conditions in background snow meltwater ( $\mathrm{pH}$ 5.6) to neutral, weak alkaline, and even alkaline in the city ( $\mathrm{pH} 7.5-8.6$ ). Under such alkaline conditions, the cationogens $\mathrm{Bi}, \mathrm{Fe}, \mathrm{Pb}, \mathrm{Rb}, \mathrm{Mn}$, $\mathrm{Co}, \mathrm{Cu}, \mathrm{Ba}, \mathrm{Mg}$, and $\mathrm{Zn}$ are poorly dissolved from the suspended particles. This is confirmed by the negative significant $r_{s}$ between the $\mathrm{pH}$ value of meltwater and the proportion of dissolved forms of $\mathrm{Cu}, \mathrm{Cd}, \mathrm{Ba}, \mathrm{Bi}, \mathrm{Fe}, \mathrm{Sn}, \mathrm{Al}$, and $\mathrm{W}$.

A comparative analysis of the chemical composition of atmospheric dust, snowmelt-runoff, and rainfall-runoff in Beijing showed the leading role of dust in the formation of precipitation composition. Its presence in the snow cover results in the predominance of suspended forms of pollutants [12]. High proportions of many MMs in the suspension along with the dissolved forms of $\mathrm{Na}, \mathrm{K}, \mathrm{Ca}, \mathrm{Sr}$, and $\mathrm{Sb}$ were also identified in snow cover on the windward slope of the Salt Lake Valley (central Wasatch Mountains), Utah, USA [111]. The predominance of suspended forms of most MMs seems to be typical of urban areas, as supported by the data on $\mathrm{Cr}, \mathrm{Pb}, \mathrm{Cu}, \mathrm{Ni}, \mathrm{Al}$, and $\mathrm{Fe}$ in snow in Östersund [15] and on $\mathrm{Pb}, \mathrm{Cu}, \mathrm{Zn}$, and $\mathrm{Cd}$ in snow in Luleå and Umeå, Sweden [16]. 

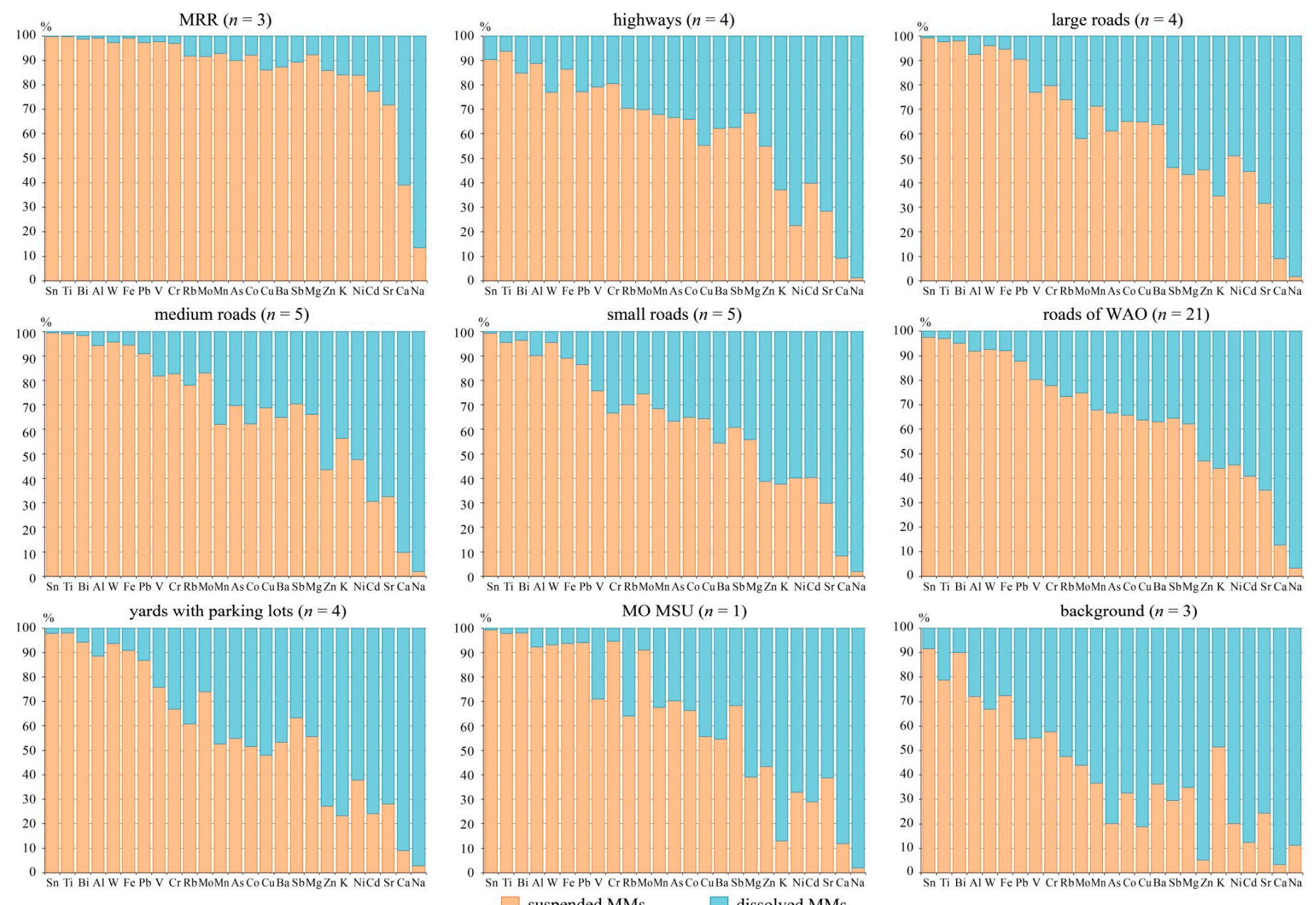

Figure 3. Proportions of dissolved and suspended MMs forms in snow cover along different types of roads, at car parking lots in the yards of residential buildings and at the MO MSU in the western part of Moscow, and in the background area. 
Concentrations of $\mathrm{Al}, \mathrm{Fe}, \mathrm{Mn}$, and $\mathrm{V}$ in snow cover of the traffic zone increase with increasing particle size reaching the maximum in particles $>1000 \mu \mathrm{m}$, while the concentrations of $\mathrm{Zn}$ and $\mathrm{Pb}$ are the highest in particles $<100 \mu \mathrm{m}$ [21]. This trend is observed even in small cities with no industrial enterprises, where the increasing contributions of $0.45-1.2 \mu \mathrm{m}, 1.2-8 \mu \mathrm{m}$, and $>8 \mu \mathrm{m}$ fractions to the total concentrations of these MMs in snow cause lower proportion of dissolved forms of $\mathrm{Al}, \mathrm{Si}$, $\mathrm{Mn}, \mathrm{Fe}$, and $\mathrm{Zn}$ compared to the background territories, as shown by the Valday case study [112]. A summary of the results of studies on the chemical composition and the ratio of pollutants in water runoff from roads at 294 monitoring points on six continents showed that $\mathrm{Pb}$ and $\mathrm{Cr}$ predominate in road runoff in suspended form, while $\mathrm{Zn}, \mathrm{Cu}, \mathrm{Ni}$, and $\mathrm{Cd}$ in dissolved form [14]. At the same time, the proportion of suspended forms of MMs in snow meltwater is usually greater than in rainwater [113].

The MRR stands out among all types of roads of the WAO in terms of the ratio of MMs forms in snow cover-the highest proportion of suspended forms of all MMs was recorded next to this highway. Mass input of dust particles leads to the dominance of suspended form for most MMs in snow cover (more than $85 \%$ ); only $\mathrm{Cd}$ and $\mathrm{Sr}$ account for $72-77 \%$. Ca and $\mathrm{Na}$ entering snow cover with easily soluble DISs prevail in dissolved forms ( $61 \%$ and $86 \%$, respectively). Medium roads, similar to the MRR, are characterized by a significant proportion $(>80 \%$ ) of suspended forms for $\mathrm{Sn}, \mathrm{Ti}, \mathrm{Bi}, \mathrm{Al}, \mathrm{W}, \mathrm{Fe}, \mathrm{Pb}, \mathrm{V}$, $\mathrm{Cr}$, and Mo and relatively low ones for $\mathrm{Zn}$ and $\mathrm{Cd}$ ( $43 \%$ and $31 \%$, respectively). A high proportion of dissolved $\mathrm{Zn}$ reaching $70 \%$ is typical of traffic area runoff [14], and of dissolved $\mathrm{Cd}$ and $\mathrm{Zn}$ for snowmelt water, in which the solubility of these metals could reach $100 \%$ and $81 \%$, respectively [15]. The ratio of MMs forms on large, small roads, and highways is scarcely different from the average level for all WAO roads.

Anthropogenic load in the yards and at the MO MSU is less pronounced compared to roads; it is evident from the content of solid particles in snow meltwater (15 and $17 \mathrm{mg} / \mathrm{L}$ compared to $48 \mathrm{mg} / \mathrm{L}$ on the roads). Therefore, the contribution of suspended MMs to the total content of elements in snow cover decreases. The MO MSU is located between two small roads-Academician Khokhlov Street and Michurinskiy Alley, used for the passage and parking of vehicles of the MSU employees. Thus, the ratio of suspended and dissolved MMs forms is close to that in the yards. At the same time, the share of dissolved $\mathrm{Cd}, \mathrm{K}, \mathrm{Zn}, \mathrm{Mg}, \mathrm{Ba}, \mathrm{Cu}$, and $\mathrm{Rb}$ increases by $10 \%$ and more in snow cover at the MO MSU and in the yards of residential buildings compared with roads. The source of these MMs could be fine particles (less than $0.45 \mu \mathrm{m}$ ) emitted during the heating of car engines at car parking lots in the yards and near the MO MSU.

This is confirmed by laboratory studies on the influence of air temperatures and the operation modes of car engines on snow pollution with particulate matter and MMs. The studies have shown that motor vehicles emissions enrich snow with particles of 50-400 nm, which are high in MMs content [19]. Therefore, when a solid phase is separated from meltwater using filters with $0.45 \mu \mathrm{m}$ pore diameter, a large number of fine MMs-contaminated particles enters the dissolved phase. Nanoparticles account for $71 \%$ of the total number of particles with $3 \mathrm{~nm}$ to $10 \mu \mathrm{m}$ diameter in snow of Montreal, and up to $19 \%$ of particles are less than $100 \mathrm{~nm}$ [114]. Particle number density of ultrafine particles $(0.01-0.1 \mu \mathrm{m}$ in diameter) in snow is dozens and hundreds of times larger than that of $0.1-0.2 \mu \mathrm{m}$ and $0.2-0.5 \mu \mathrm{m}$ particles. However, a significant proportion of $\mathrm{Al}, \mathrm{Cr}, \mathrm{Mn}, \mathrm{Co}, \mathrm{Ni}, \mathrm{Cu}, \mathrm{As}, \mathrm{Cd}$, and $\mathrm{Pb}$ is in suspended form, that is, it is associated with particles larger than $0.2 \mu \mathrm{m}$, although the ultrafine fraction also plays an important role in the formation of total MMs content in snow [22].

Study of the composition of atmospheric particles in Hong Kong revealed that the proportion of water-soluble MMs in $\mathrm{PM}_{2.5}$ fraction is $10-25 \%$ higher than in the $\mathrm{PM}_{10}$ fraction. Moreover, $\mathrm{Ca}$, $\mathrm{Mg}, \mathrm{Cd}, \mathrm{Zn}, \mathrm{V}, \mathrm{Cu}, \mathrm{Mn}$, and Ni prevail in dissolved form in $\mathrm{PM}_{2.5}$ fraction, compared to just $\mathrm{Ca}$, $\mathrm{Mg}, \mathrm{Cd}$, and $\mathrm{Zn}$ in $\mathrm{PM}_{10}$ [84]. Residential buildings often form enclosed spaces, or "well traps," in which the migration of particles in the atmosphere diminishes sharply and soil pollution with MMs in the yards increases [100] due to deposition of fine particles, thus contributing to a higher proportion of dissolved forms of MMs in snow cover. Probably for the same reason, the proportion of dissolved forms of most MMs (except $\mathrm{Ni}, \mathrm{K}$, and $\mathrm{Mg}$ ) in snow cover of the yards is higher than at the MO MSU. 
The traffic intensity at car parking lots is low-even near stores, the vehicles' turnover usually does not exceed 50 units per day per 1 parking place [115]; nevertheless, the runoff from these areas is usually highly enriched with many MMs as compared to highways with light traffic intensity [14].

Thus, $\mathrm{Sn}, \mathrm{Ti}, \mathrm{Bi}, \mathrm{Al}, \mathrm{W}, \mathrm{Fe}, \mathrm{Pb}, \mathrm{V}, \mathrm{Cr}, \mathrm{Rb}, \mathrm{Mo}, \mathrm{Mn}, \mathrm{As}, \mathrm{Co}, \mathrm{Cu}, \mathrm{Ba}, \mathrm{Sb}$, and $\mathrm{Mg}$ dominate in suspended form in snow cover in the western part of Moscow. $\mathrm{Ca}$ and $\mathrm{Na}$ prevail in the dissolved form, and the contribution of suspended and dissolved forms of $\mathrm{Zn}, \mathrm{K}, \mathrm{Ni}, \mathrm{Cd}$, and $\mathrm{Sr}$ to their total content ranges from 40 to $60 \%$, that is, they lack a clearly pronounced predominant form of occurrence.

\subsection{Deposition Rates of Dissolved and Suspended MMs}

To assess geochemical impact on the components of urban landscapes during the snow occurrence period, it is necessary to determine the accumulated supplies of MMs released during snow melting. The content of particulate matter and MMs in snow meltwater of urban areas is greater than in rainfall-runoff, indicating the crucial role of snow melting for the formation of chemical composition of river runoff $[12,15]$. Snow-covered areas near different types of roads, in the yards, and in the background territory are quite different, because the city territory is severely fragmented by the road network and buildings. Therefore, the correct comparison of the supplies of pollutants in snow cover of different territories is only possible using specific parameters (per unit area). Normalizing of supplies by the number of days of snow occurrence shows the accumulation of pollutants per unit area and per time unit, i.e., the daily intensity of deposition (flux) of pollutants from the atmosphere. Since the concentrations of dissolved and suspended forms of MMs are expressed in $\mu \mathrm{g} / \mathrm{L}$, data on water content in snow cover in $\mathrm{L} / \mathrm{m}^{2}$ are used to estimate the intensity of pollutants deposition.

The mean, minimum, and maximum values of the dissolved and suspended forms of MMs deposition from the atmosphere near the roads, in the yards of WAO, at the MO MSU, and in the background area are given in Table 5 .

High levels of daily deposition in dissolved form are typical for major elements in precipitation, namely $\mathrm{Na}, \mathrm{Ca}, \mathrm{K}$, and $\mathrm{Mg}$; elements of the upper continental crust, i.e., $\mathrm{Al}$ and $\mathrm{Fe}$, as well as $\mathrm{Ti}$, are added to them if we consider the deposition in suspended form. Deposition of dissolved $\mathrm{Na}, \mathrm{Ca}, \mathrm{Sr}$, $\mathrm{Mo}, \mathrm{K}, \mathrm{W}, \mathrm{Sb}, \mathrm{V}(\mathrm{DF}>5$ ) and suspended $\mathrm{Ca}, \mathrm{W}, \mathrm{Co}, \mathrm{V}, \mathrm{Ti}, \mathrm{Sr}, \mathrm{Mg}, \mathrm{Na}, \mathrm{Mo}, \mathrm{Zn}, \mathrm{Fe}, \mathrm{Sb}, \mathrm{Al}, \mathrm{Cu}, \mathrm{As}$, $\mathrm{Sn}, \mathrm{Ba}(D F>25)$ in roadside snow cover showed the largest excess above the background values. The list of priority pollutants is shorter at car parking lots in the yards of residential buildings of the Moscow WAO and the MO MSU. In the yards compared to the background areas, the highest excess of deposition rates are found for dissolved $\mathrm{Na}, \mathrm{K}$, and $\mathrm{Sr}(D F>5)$ and suspended $\mathrm{Ca}, \mathrm{Sn}$, and $\mathrm{Mo}(\mathrm{DF}>10)$, while dissolved $\mathrm{Na}, \mathrm{K}, \mathrm{Sr}$, and $\mathrm{V}$ and suspended $\mathrm{Zn}, \mathrm{Mo}, \mathrm{Cr}, \mathrm{Sr}, \mathrm{V}, \mathrm{Pb}, \mathrm{Cu}, \mathrm{Ca}, \mathrm{As}$, $\mathrm{Sn}$, and $\mathrm{Sb}$ are characterized by the highest excess of deposition rates at the MO MSU, compared to the background areas. Thus, the snow cover composition and MMs deposition intensity for the MO MSU territory showed intermediate values between yards and roads. This is mainly due to the amount and composition of deposited dust within MO MSU, since the distribution pattern of the dissolved forms is practically similar to the yards.

The total excess of MMs deposition rates over the background level is represented by the integral $T D F$ index. For the dissolved MMs phase, the TDF value depends on the size of the road: it is maximum for the highways (446), on the MRR it is 264; it decreases to 186 on large roads, to 143 on medium roads and to 116 on small ones (Figure 4). 
Table 4. Mean, minimum, and maximum daily deposition rates of dissolved and suspended forms of MMs near roads, at car parking lots in the yards of residential buildings, near the MO MSU, and in the background area in March $2018, \mu \mathrm{g} / \mathrm{m}^{2}$ per day.

\begin{tabular}{|c|c|c|c|c|c|c|c|c|c|c|c|c|c|c|c|c|c|c|c|c|}
\hline \multirow{3}{*}{ MMs } & \multicolumn{10}{|c|}{ Dissolved Forms } & \multicolumn{10}{|c|}{ Suspended Forms } \\
\hline & \multicolumn{3}{|c|}{ Roads $(n=21)$} & \multicolumn{3}{|c|}{ Yards $(n=4)$} & \multirow{2}{*}{$\begin{array}{c}\text { MO } \\
\text { MSU }(n=1) \\
\text { Mean }\end{array}$} & \multicolumn{3}{|c|}{ Background $(n=3$ ) } & \multicolumn{3}{|c|}{ Roads $(n=21)$} & \multicolumn{3}{|c|}{ Yards $(n=4)$} & \multirow{2}{*}{$\begin{array}{c}\text { MO } \\
\text { MSU }(n=1) \\
\text { Mean }\end{array}$} & \multicolumn{3}{|c|}{ Background $(n=3)$} \\
\hline & Mean & Min. & Max. & Mean & Min. & Max. & & Mean & Min. & Max. & Mean & Min. & Max. & Mean & Min. & Max. & & Mean & Min. & Max. \\
\hline $\mathrm{Na}$ & 27511 & 3489 & 98917 & 7695 & 2160 & 19791 & 6666 & 211 & 154 & 275 & 1189 & 95 & 13321 & 134 & 60 & 233 & 134 & 25 & 16 & 35 \\
\hline $\mathrm{Mg}$ & 299 & 107 & 932 & 137 & 110 & 152 & 282 & 54 & 45 & 69 & 1415 & 115 & 15400 & 188 & 91 & 310 & 181 & 29 & 21 & 35 \\
\hline $\mathrm{Al}$ & 95 & 41 & 247 & 85 & 48 & 150 & 66 & 61 & 55 & 65 & 5382 & 383 & 59597 & 683 & 330 & 1115 & 783 & 170 & 99 & 244 \\
\hline $\mathrm{K}$ & 665 & 122 & 1588 & 783 & 353 & 1288 & 1363 & 54 & 45 & 69 & 1060 & 122 & 10577 & 204 & 94 & 328 & 201 & 62 & 35 & 97 \\
\hline $\mathrm{Ca}$ & 19997 & 3476 & 61603 & 5851 & 3086 & 7865 & 4383 & 1475 & 1191 & 1705 & 5104 & 309 & 54910 & 603 & 250 & 1054 & 587 & 51 & 38 & 74 \\
\hline $\mathrm{Ti}$ & 2.4 & 0.31 & 14 & 1.1 & 0.75 & 1.5 & 1.3 & 1.2 & 0.9 & 1.6 & 440 & 42 & 4764 & 63 & 32 & 103 & 55 & 8.4 & 1.8 & 16 \\
\hline V & 1.2 & 0.21 & 3.7 & 0.93 & 0.27 & 2.2 & 1.4 & 0.22 & 0.18 & 0.27 & 15 & 1.2 & 165 & 2.6 & 1.5 & 3.4 & 3.4 & 0.28 & 0.16 & 0.41 \\
\hline $\mathrm{Cr}$ & 0.84 & 0.52 & 4.9 & 0.63 & 0.55 & 0.68 & 0.61 & 0.54 & 0.45 & 0.69 & 13 & 0.48 & 171 & 1.4 & 0.65 & 2.2 & 11 & 0.76 & 0.48 & 0.99 \\
\hline $\mathrm{Mn}$ & 14 & 4.3 & 110 & 16 & 3.5 & 46 & 4.8 & 5.1 & 3.1 & 8.5 & 71 & 6.7 & 737 & 11 & 5.0 & 19 & 10 & 3.0 & 1.1 & 5.3 \\
\hline $\mathrm{Fe}$ & 116 & 34 & 479 & 89 & 41 & 126 & 57 & 52 & 42 & 65 & 4898 & 492 & 47751 & 884 & 422 & 1405 & 833 & 144 & 91 & 197 \\
\hline Co & 0.36 & 0.14 & 1.4 & 0.24 & 0.13 & 0.41 & 0.13 & 0.074 & 0.067 & 0.082 & 2.1 & 0.16 & 23 & 0.25 & 0.12 & 0.42 & 0.27 & 0.037 & 0.027 & 0.053 \\
\hline $\mathrm{Ni}$ & 5.6 & 1.9 & 36 & 2.2 & 1.9 & 2.4 & 4.4 & 1.9 & 1.6 & 2.4 & 7.7 & 0.56 & 93 & 1.4 & 0.74 & 1.8 & 2.1 & 0.47 & 0.35 & 0.64 \\
\hline $\mathrm{Cu}$ & 6.6 & 3.0 & 17 & 5.2 & 3.6 & 6.6 & 6 & 3.1 & 2.5 & 3.9 & 21 & 2.3 & 148 & 4.9 & 2.8 & 6.0 & 7.5 & 0.7 & 0.62 & 0.79 \\
\hline $\mathrm{Zn}$ & 21 & 13 & 37 & 24 & 15 & 31 & 29 & 25 & 15 & 43 & 42 & 4.3 & 380 & 9.0 & 4.0 & 12 & 22 & 1.2 & 0.61 & 1.6 \\
\hline As & 0.064 & 0.052 & 0.084 & 0.064 & 0.055 & 0.068 & 0.061 & 0.054 & 0.045 & 0.069 & 0.35 & 0.016 & 3.2 & 0.1 & 0.015 & 0.14 & 0.14 & 0.013 & 0.011 & 0.015 \\
\hline $\mathrm{Rb}$ & 0.55 & 0.23 & 1.2 & 0.45 & 0.32 & 0.7 & 0.42 & 0.21 & 0.16 & 0.25 & 3.9 & 0.46 & 39 & 0.73 & 0.37 & 1.1 & 0.74 & 0.21 & 0.11 & 0.34 \\
\hline $\mathrm{Sr}$ & 18 & 6.09 & 53 & 9.3 & 5.7 & 16 & 8.7 & 1.3 & 0.99 & 1.8 & 22 & 2.0 & 233 & 3.4 & 2.0 & 5.6 & 5.5 & 0.42 & 0.27 & 0.67 \\
\hline Mo & 0.32 & 0.03 & 4.0 & 0.091 & 0.028 & 0.2 & 0.031 & 0.027 & 0.023 & 0.034 & 0.9 & 0.09 & 8.5 & 0.21 & 0.11 & 0.27 & 0.31 & 0.021 & 0.019 & 0.023 \\
\hline $\mathrm{Cd}$ & 0.087 & 0.025 & 0.8 & 0.082 & 0.035 & 0.16 & 0.075 & 0.036 & 0.016 & 0.049 & 0.067 & 0.009 & 0.52 & 0.024 & 0.01 & 0.035 & 0.031 & 0.006 & 0.001 & 0.011 \\
\hline Sn & 0.017 & 0.005 & 0.23 & 0.016 & 0.006 & 0.045 & 0.006 & 0.005 & 0.005 & 0.007 & 1.7 & 0.38 & 12 & 0.75 & 0.42 & 0.95 & 0.69 & 0.066 & 0.039 & 0.089 \\
\hline $\mathrm{Sb}$ & 0.47 & 0.12 & 4.8 & 0.16 & 0.1 & 0.22 & 0.15 & 0.074 & 0.06 & 0.1 & 1.0 & 0.12 & 9.8 & 0.27 & 0.17 & 0.34 & 0.32 & 0.03 & 0.021 & 0.04 \\
\hline $\mathrm{Ba}$ & 12 & 5.2 & 39 & 8.4 & 5.6 & 12 & 9.5 & 3.0 & 2.0 & 4.6 & 43 & 5.4 & 417 & 9.6 & 6.4 & 13 & 11 & 1.7 & 0.92 & 2.9 \\
\hline W & 0.14 & 0.021 & 0.96 & 0.025 & 0.022 & 0.027 & 0.025 & 0.022 & 0.018 & 0.027 & 3.3 & 0.3 & 34 & 0.42 & 0.21 & 0.64 & 0.33 & 0.046 & 0.034 & 0.061 \\
\hline $\mathrm{Pb}$ & 0.44 & 0.15 & 1.9 & 0.36 & 0.23 & 0.6 & 0.66 & 0.76 & 0.48 & 1.1 & 6.3 & 0.5 & 46 & 2.3 & 1.7 & 2.7 & 11 & 0.91 & 0.65 & 1.1 \\
\hline $\mathrm{Bi}$ & 0.003 & 0.001 & 0.032 & 0.003 & 0.0013 & 0.007 & 0.0012 & 0.0011 & 0.0009 & 0.0014 & 0.12 & 0.025 & 0.81 & 0.044 & 0.04 & 0.048 & 0.058 & 0.012 & 0.007 & 0.02 \\
\hline
\end{tabular}




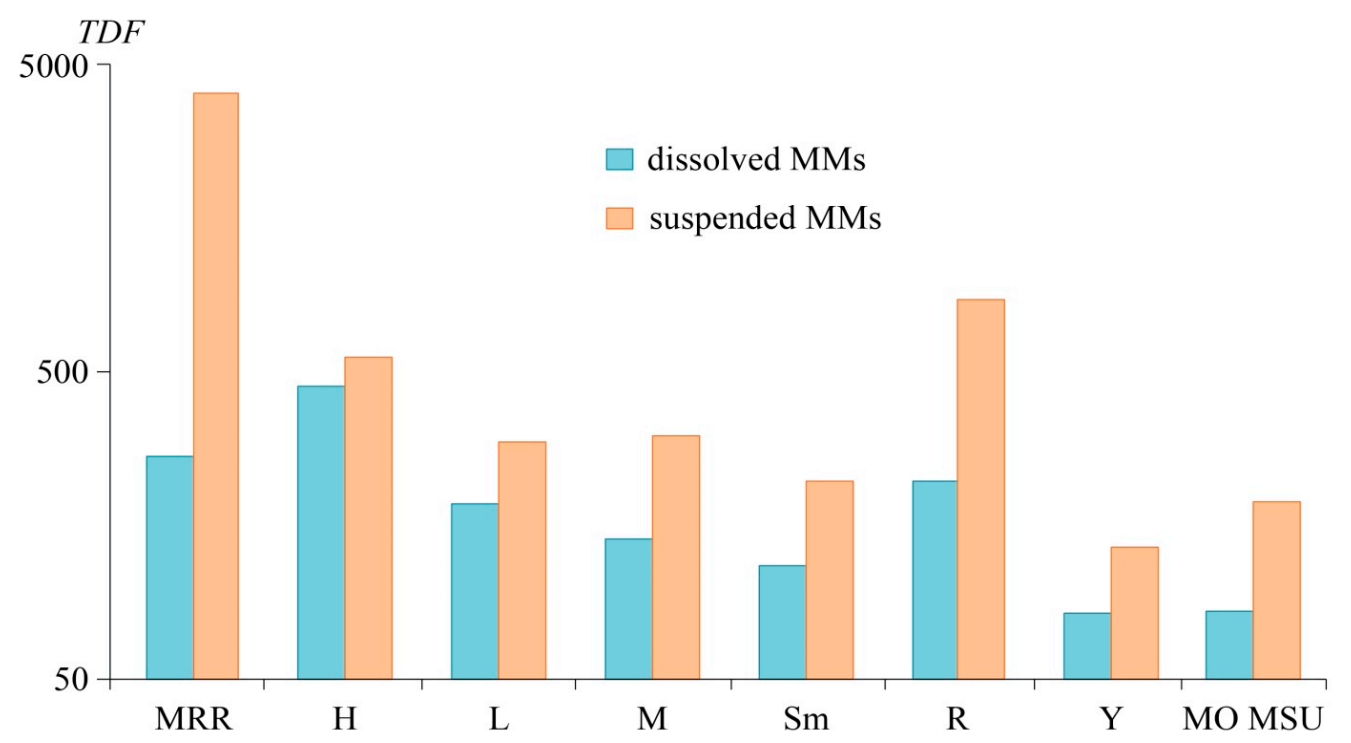

Figure 4. Total excess of daily deposition of dissolved and suspended forms of MMs over the background level for different territories: $\mathrm{H}$-highways, $\mathrm{L}$-large roads, $\mathrm{M}$ - medium roads, $\mathrm{Sm}$-small roads, $\mathrm{R}$-all roads of the Moscow WAO, $\mathrm{Y}$ - car parking lots in the yards of residential buildings.

High TDF values are marked for Kutuzovskiy Avenue and Mozhaiskoye highway—648 and 529, respectively (Figure 5). Increased values of the integral index (TDF $>250)$ were also calculated for the MRR, Rublevskoye, and Aminievskoye highways and Minskaya Street (a large road). TDF values are approximately the same in the yards and at the MO MSU (82 and 83, respectively). In addition, the changes in TDF values are determined by the accumulation of $\mathrm{Na}$ : the share of this metal to TDF is $67-68 \%$ for the MRR and the highways, decreasing to $59 \%$ for medium roads due to the less intensive use of DISs, to $51 \%$ for small roads, $45 \%$ in the yards, and $38 \%$ at the MO MSU. However, the contribution of $\mathrm{Na}$ is only $38 \%$ for large roads, because of the intensive input of dissolved forms of Mo and $\mathrm{Sb}$ (DF 40 and 19, respectively). A significant contribution of $\mathrm{Ca}, \mathrm{Sr}$, and $\mathrm{K}$ is common to all types of roads.

The maximum value of the integral TDF index for suspended phase, reaching 4039, is found for the MRR, due to intense deposition of a wide range of MM, among which $(D F>100$, and written in subscript) are $\mathrm{Ca}_{491} \mathrm{~W}_{328} \mathrm{Co}_{281} \mathrm{Ti}_{261} \mathrm{~V}_{261} \mathrm{Sr}_{255} \mathrm{Mg}_{246} \mathrm{Na}_{243} \mathrm{Mo}_{173} \mathrm{Al}_{161} \mathrm{Fe}_{153} \mathrm{Zn}_{147} \mathrm{Sb}_{140} \mathrm{Mn}_{113} \mathrm{Ba}_{109} \mathrm{As}_{105}$. Similar to suspended MMs, TDF values for dissolved MMs decrease with diminishing road size: it is 553 for the highways, 294 and 308 for large and medium roads, respectively, 220 for small ones and 135 for the yards (Figure 4). The highest TDF values at all points studied on the MRR and the increased values (TDF $>500$ ) on Kutuzovskiy Avenue, Mozhaiskoye and Aminievskoye highways, and Minskaya Street (Figure 5) evidence that the anomalies of dissolved and suspended MMs depositions generally coincide. Lower TDF values of suspended MMs on Rublevskoye highway could be caused by the low content of solid particles in meltwater $(12 \mathrm{mg} / \mathrm{L}$ compared to $78-102 \mathrm{mg} / \mathrm{L}$ in snow cover next to the MRR, $170 \mathrm{mg} / \mathrm{L}$ along Kutuzovskiy Avenue and $95 \mathrm{mg} / \mathrm{L}$ along Mozhaiskoye highway).

The TDF value for suspended MMs within the MO MSU area lies between values for small roads and yards and equals to 189. There is no particular element leading in its contribution to TDF in suspended phase compared with dissolved one: the input of $\mathrm{Zn}$ averages $10 \%$, those of $\mathrm{Ca}, \mathrm{V}, \mathrm{Cr}, \mathrm{Cu}$, $\mathrm{As}, \mathrm{Sr}, \mathrm{Mo}, \mathrm{Sn}, \mathrm{Sb}$, and $\mathrm{Pb}-6-8 \%$, and $5 \%$ or less of other MMs. On the roads, the contribution of $\mathrm{Ca}$ is 7-13\%, W-7-10\%, Mo and Cu-below 9\%, Co and V-below 8\%, Sn and Ti-below 7\%, Sb, Zn, Sr, $\mathrm{Mg}$, and $\mathrm{Na}-$ below $6 \%$, and the rest $\mathrm{MMs}-5 \%$ or less. In the yards, the contribution of $\mathrm{Ca}$ is $9 \%$, Mo, $\mathrm{Sn}, \mathrm{Sb}, \mathrm{W}, \mathrm{V}, \mathrm{Zn}, \mathrm{As}, \mathrm{Ti}$, and $\mathrm{Sr}-6-8 \%$, and the rest MMs- $5 \%$ or less. 


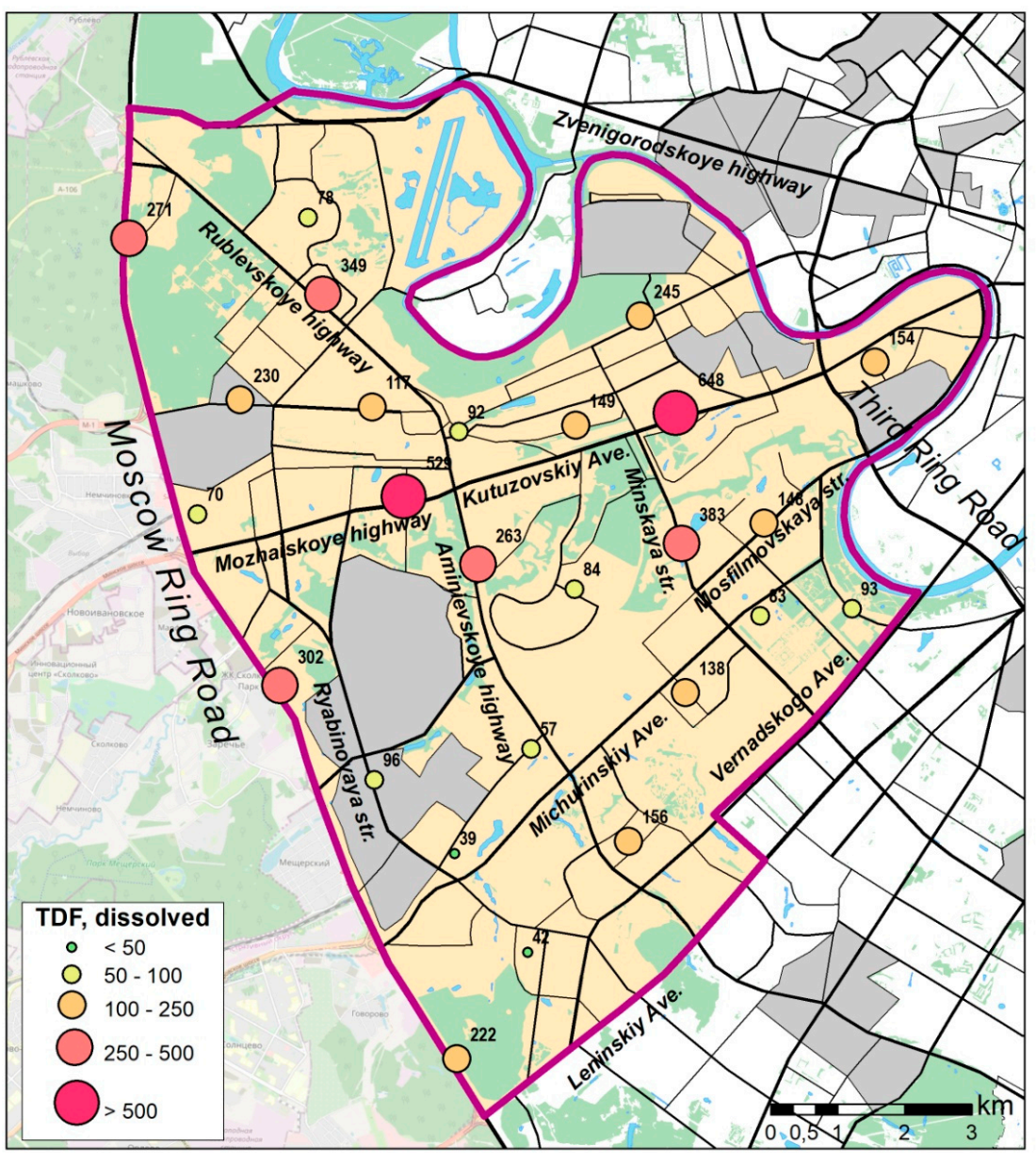

(a) Dissolved MMs

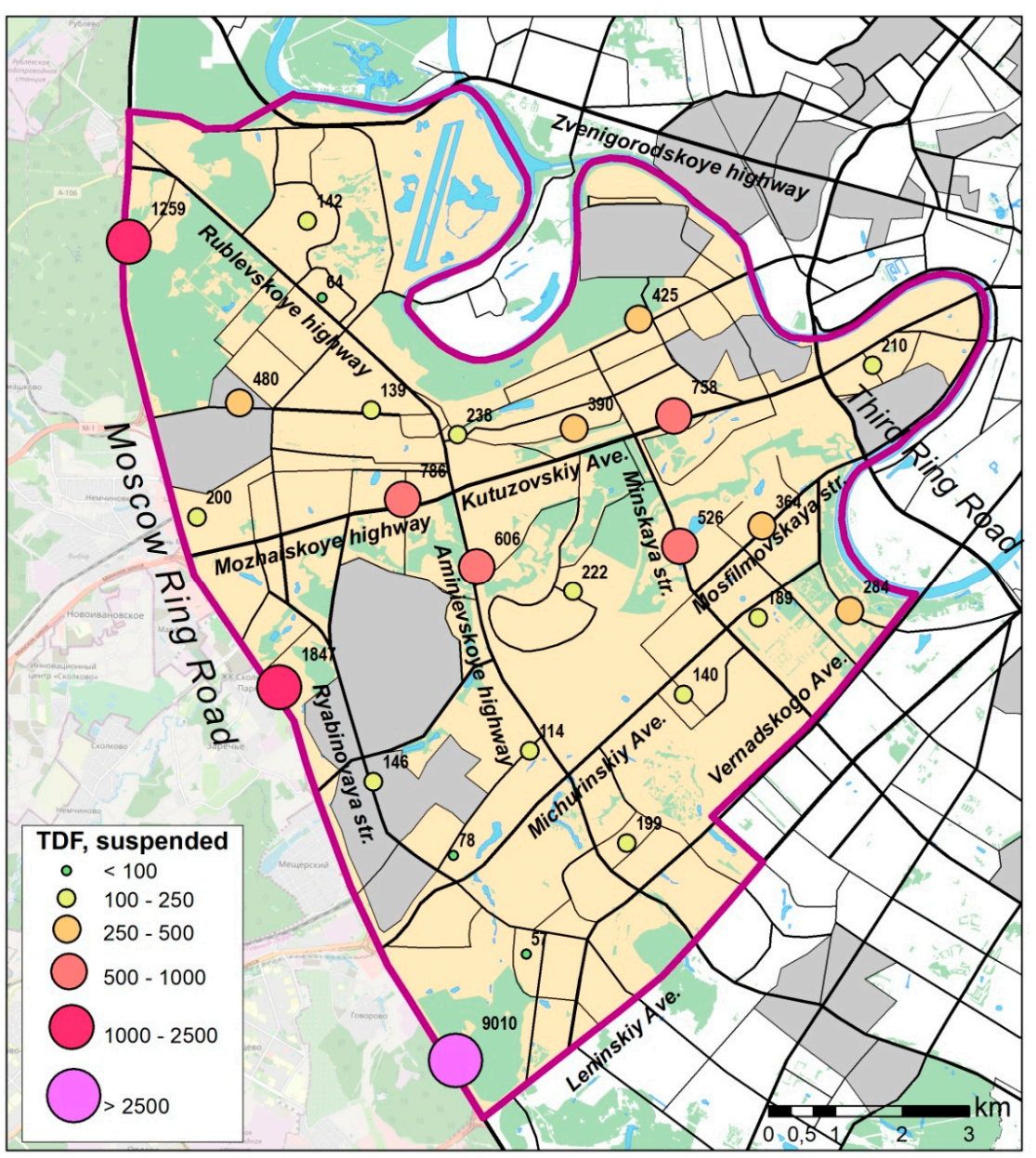

(b) Suspended MMs

Figure 5. Distribution of integral TDF index values for dissolved and suspended MMs forms in the western part of Moscow. 
The average TDF value for suspended forms is 864; the elements form the following series in terms of DF values: $\mathrm{Ca}_{100} \mathrm{~W}_{71} \mathrm{Co}_{56} \mathrm{~V}_{54} \mathrm{Ti}_{52} \mathrm{Sr}_{52} \mathrm{Mg}_{49} \mathrm{Na}_{48} \mathrm{Mo}_{43} \mathrm{Zn}_{36} \mathrm{Fe}_{34} \mathrm{Sb}_{33} \mathrm{Al}_{32} \mathrm{Cu}_{30} \mathrm{As}_{26} \mathrm{Sn}_{25} \mathrm{Ba}_{25} \mathrm{Mn}_{23} \mathrm{Rb}_{19}$ $\mathrm{Cr}_{17} \mathrm{~K}_{17} \mathrm{Ni}_{16} \mathrm{Cd}_{11} \mathrm{Bi}_{10} \mathrm{~Pb}_{7}$. This pattern of deposition differs from what we received earlier for the roads of the Eastern Administrative Okrug of Moscow, where the TDF value for suspended MMs was 609 with the following excesses of deposition over the background: $\mathrm{Mo}_{380} \mathrm{~W}_{45} \mathrm{Sb}_{31} \mathrm{As}_{27} \mathrm{Sn}_{18} \mathrm{Fe}_{15} \mathrm{Sr}_{14} \mathrm{~V}_{13} \mathrm{Co}_{11}$ $\mathrm{Cr}_{11} \mathrm{Mn}_{10} \mathrm{Ni}_{9} \mathrm{Ti}_{8} \mathrm{Zn}_{8} \mathrm{Cu}_{7} \mathrm{Bi}_{6} \mathrm{Ag}_{6} \mathrm{Cd}_{5} \mathrm{Be}_{4} \mathrm{~Pb}_{3}$ [46]. However, the calculation of TDF in the Eastern Okrug did not consider major elements that play an important role in snow cover pollution, such as $\mathrm{Ca}, \mathrm{Mg}$, $\mathrm{Na}, \mathrm{K}$, and $\mathrm{Al}$, as well as $\mathrm{Ba}$ and $\mathrm{Rb}$. If these elements are ignored, the TDF for the Western Okrug will be 574 , which is very close to its value in the eastern industrial part of Moscow.

\subsection{Indication of Sources (Cluster Analysis)}

Sources of dissolved and suspended MMs in the snow cover of the western part of Moscow were identified by cluster analysis (Figure 6). Seven MMs associations were distinguished for dissolved forms, i.e., $\mathrm{Cl}-\mathrm{Na}-\mathrm{Sr}-\mathrm{Ca}(r=0.86-0.99), \mathrm{Mg}-\mathrm{HCO}_{3}{ }^{-}(r=0.50), \mathrm{Mo}-\mathrm{Sb}_{-} \mathrm{SO}_{4}{ }^{2-}(r=0.45-0.99), \mathrm{K}^{-} \mathrm{NO}_{3}{ }^{-}(r=0.57)$, $\mathrm{Mn}-\mathrm{Cd}-\mathrm{Cu}-\mathrm{Co}-\mathrm{Rb}(r=0.50-0.95)$, Ti-Fe-Pb-Al-Sn-Bi-W ( $r=0.78-0.97), \mathrm{Cr}-\mathrm{Ba}-\mathrm{Ni}(r=0.82-0.87)$; no associations for $\mathrm{V}$ and $\mathrm{Zn}$ were found. It is well known that coarse particles in the snow are carried over shorter distances compared to fine particles $(<0.45 \mu \mathrm{m})$, so their composition is more uniform and depends mainly on the adjacent sources. Therefore, fewer associations of suspended forms of MMs are formed compared to dissolved ones (4 vs 7), but they contain greater number of MMs, i.e., Ni-Al-Mg-Ti-Ca-Sr-Mn-Co-W-K-Rb-Ba-Ni-Fe-V ( $r=0.94-0.99), \mathrm{Cr}-\mathrm{Zn}(r=0.97)$, Mo-Sb-Cd-As ( $r=0.91-0.97)$, $\mathrm{Sn}-\mathrm{Bi}(r=0.91)$; no associations for $\mathrm{Cu}$ and $\mathrm{Pb}$ were identified.

DISs are a most important source of MMs in the snow cover of WAO, which is clearly manifested in the associations of dissolved $\mathrm{Cl}-\mathrm{Na}-\mathrm{Sr}-\mathrm{Ca}$ and $\mathrm{Mg}-\mathrm{HCO}_{3}{ }^{-}$, since $\mathrm{Na}, \mathrm{Ca}$, and $\mathrm{Mg}$ chlorides, as well as $\mathrm{Ca}$ and $\mathrm{Mg}$ carbonates are mainly used as DISs in Moscow [75]. Their consumption for single road treatment is $80-200 \mathrm{~g} / \mathrm{m}^{2}$ [116]. Moscow community services apply liquid DISs at temperatures higher than $-16^{\circ} \mathrm{C}$; at lower temperatures, combined ones are applied, which include marble chips (up to $50-60 \%$ ), and crystals of calcium chloride and formic acid salts. The solubility of marble is low, but it increases with diminishing size of its chips in the presence of dissolved calcium chloride and pavement particles [70]. Only combined DISs are approved for application in the yards, grounds surrounding residential buildings, sidewalks, and pedestrian streets of Moscow. DISs and the construction dust of carbonate composition could also be a source of $\mathrm{Sr}$, since this metal is often contained in $\mathrm{Ca}$ and $\mathrm{Mg}$ carbonates [117].

Large amounts of MMs accumulate in snow cover as a result of soil and road dust particles transfer. They are resuspended from the road surface during long snowless periods and from the snow-free areas [4], as well as when cars spray particles of contaminated material accumulated on the road surface and consisting of snow, DISs, dirt from the car wheels, and a large mass of soil particles [21]. Input of a large group of MMs as a result of blowing and splashing mud material from the surface of roads is indicated by the formation of associations of suspended $\mathrm{Ni}-\mathrm{Al}-\mathrm{Mg}-\mathrm{Ti}-\mathrm{Ca}-\mathrm{Sr}-\mathrm{Mn}-\mathrm{Co}-\mathrm{W}-\mathrm{K}-\mathrm{Rb}-\mathrm{Ba}-\mathrm{Ni}-\mathrm{Fe}-\mathrm{V}$ and dissolved Ti-Fe-Pb-Al-Sn-Bi-W. Thus, $\mathrm{Al}, \mathrm{Ti}, \mathrm{Fe}, \mathrm{Mn}, \mathrm{Rb}$, and $\mathrm{K}$ come predominantly with soil particles upon blowing [118-120]; $\mathrm{Na}, \mathrm{Ca}, \mathrm{Mg}$, and $\mathrm{Sr}$ - with construction dust and large DISs particles; $\mathrm{W}, \mathrm{Sn}, \mathrm{Bi}, \mathrm{Co}, \mathrm{Ni}, \mathrm{Ba}, \mathrm{Pb}$, and Ti-with various size fractions of road dust $[67,95,119,121-125]$.

The input of elements into snow cover from roadside areas is difficult to separate from their entry with car emissions, since both road dust and roadside soils are partly polluted with MMs by vehicles emissions. Therefore, wear of brake pads and other metal parts of vehicles leads to the formation of associations of dissolved $\mathrm{Cr}-\mathrm{Ba}-\mathrm{Ni}$ and suspended $\mathrm{Cr}-\mathrm{Zn}$, and probably dissolved $\mathrm{Mo}-\mathrm{Sb}-\mathrm{SO}_{4}{ }^{2-}$ together with suspended $\mathrm{Sn}-\mathrm{Bi}$ and $\mathrm{Mo}-\mathrm{Sb}-\mathrm{Cd}-\mathrm{As}$ in roadside snow. The assumption is supported by the results of studies in which $\mathrm{Ba}, \mathrm{Zn}, \mathrm{Sb}, \mathrm{Sn}, \mathrm{Mo}, \mathrm{Bi}, \mathrm{Cr}$, and $\mathrm{Ni}$ were proved to be indicator elements for such effects of motor vehicles $[91,93,118,120,126-130]$. Ba and $\mathrm{Sb}$ sulphates used as a 
friction modifier in the production of brake linings [131], as well as antimony sulfide (III)- $\mathrm{Sb}_{2} \mathrm{~S}_{3}$, which is a component of brake lubricant [92] could be sources of sulfate ion in snow cover.
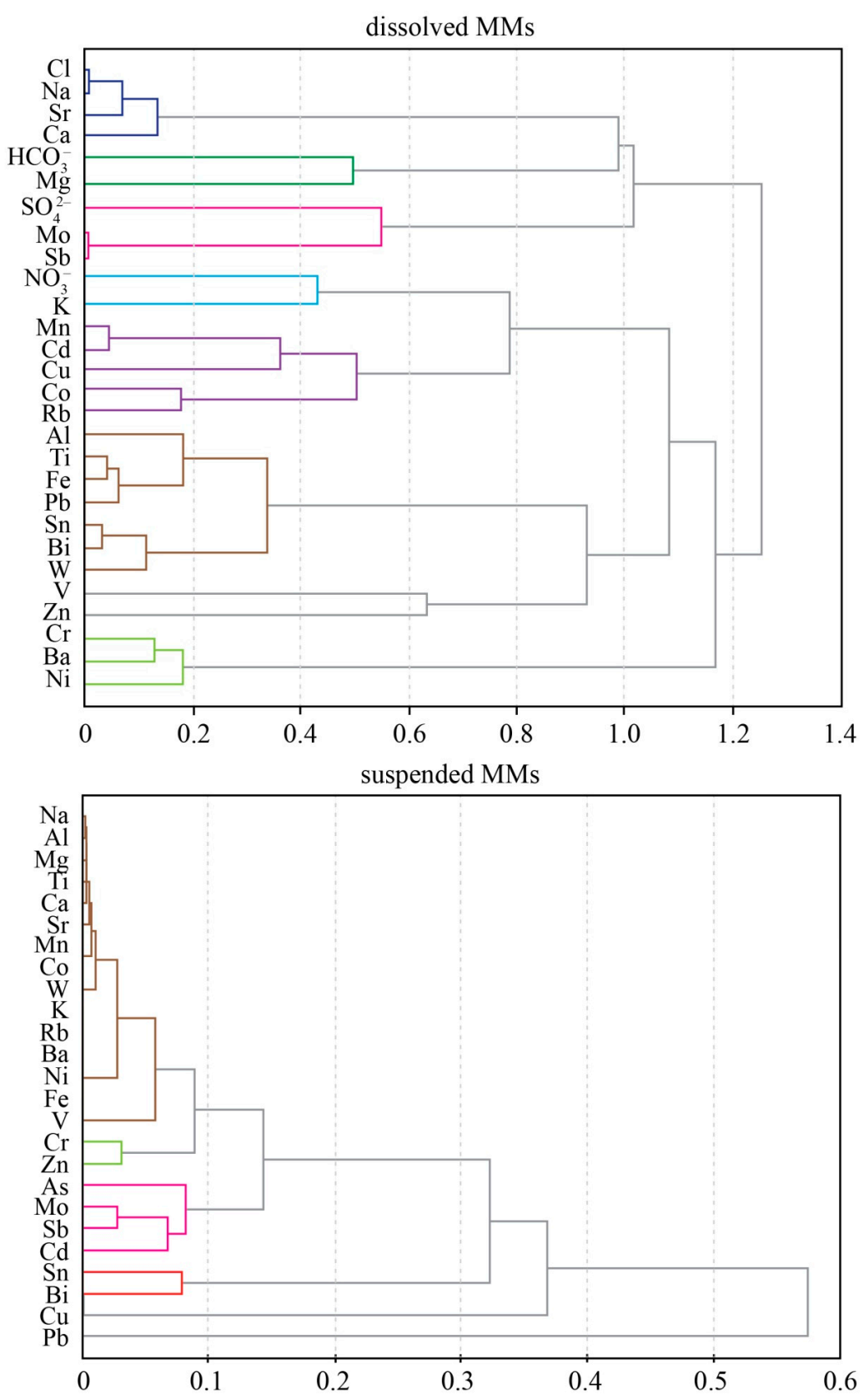

Figure 6. Dendrograms of dissolved and suspended MMs in snow cover of the western part of Moscow. Results of cluster analysis (amalgamation rule: Complete Linkage, distance measure: $d=1$-Pearson $r$ ).

Abrasion of tires and the roadway surface causes the formation of the association of dissolved $\mathrm{Mn}-\mathrm{Cd}-\mathrm{Cu}-\mathrm{Co}-\mathrm{Rb}$ in roadside snow cover of the Moscow WAO. These MMs are often used as indicators of this type of transport impact $[89,93,118,126,127]$. In addition, $\mathrm{Zn}, \mathrm{Cr}, \mathrm{Mo}$, and $\mathrm{Sb}$ are indicators of tire abrasion [122,127], while $\mathrm{Cu}, \mathrm{Cd}$, and $\mathrm{Mn}$ indicate brake pads and linings wearing $[89,119,121,122,126]$. However, the consideration of brake pads abrasion and tire wear as separate factors is rather questionable because they form a wide range of MMs associations. Therefore, the abrasion of brake pads and tires is sometimes classified as a single "vehicle abrasion" factor [118].

Vehicle exhausts contribute to the formation of dissolved $\mathrm{K}-\mathrm{NO}_{3}{ }^{-}$association in roadside snow cover. Most commonly, the input of $\mathrm{K}$ is attributed to the combustion of organic residues, biomass, 
or coal [132-134]. However, there are no significant sources of biomass combustion within the WAO territory, and power plants burn mainly natural gas in winter, so the input of $\mathrm{K}$ and $\mathrm{NO}_{3}{ }^{-}$from vehicles seems more likely. Moreover, significant correlations of $\mathrm{NO}_{3}{ }^{-}$with dissolved $\mathrm{Cu}(r=0.62)$ and $\mathrm{Rb}(r=0.42)$, and of dissolved $\mathrm{K}$ with dissolved forms of $\mathrm{Rb}(r=0.75), \mathrm{Cu}(r=0.64), \mathrm{Sr}(r=0.52)$, $\mathrm{Co}(r=0.52), \mathrm{W}(r=0.47), \mathrm{Cl}(r=0.41)$, and $\mathrm{Na}(r=0.39)$ are typical of snow cover in WAO. This may indicate additional input of $\mathrm{K}_{\text {and }} \mathrm{NO}_{3}{ }^{-}$with DISs (in the form of $\mathrm{KCl}$, or as impurities to the DISs of chloride composition), as well as when blowing and splashing road dust and soil particles, sometimes with admixed potassium and nitrogen fertilizers.

The anthropogenic impact of industrial enterprises in the western part of Moscow is less intense than that of vehicles, but this source could contribute to the formation of dissolved $\mathrm{Mo}-\mathrm{Sb}-\mathrm{SO}_{4}{ }^{2-}$ association in snow cover. Despite the fact that Moscow thermal power plants burn mainly natural gas during the heating season, fuel oil is also used there during severe and prolonged frosts as an additional fuel. This contributes to higher $\mathrm{SO}_{2}$ emissions into the atmospheric air [77] and, probably, increases $\mathrm{SO}_{4}{ }^{2-}$ concentrations in snow cover.

Both the dissolved forms of $\mathrm{V}$ and $\mathrm{Zn}$, and suspended forms of $\mathrm{Cu}$ and $\mathrm{Pb}$ could come in different amounts from all the above-discussed sources. Thus, no close associations with other MMs were found for these elements.

\section{Conclusions}

The undertaken studies proved the significant impact of motor transport, industrial facilities, and DISs on urban snow cover pollution. The obtained data made it possible to define in detail the snow cover pollution pattern of snow over in the western part of Moscow, which could be used to predict the after-snowmelt fate of MMs in other urban environments.

In the western part of Moscow, anthropogenic impact caused a significant increase of dust load (2-7 times), concentration of solid particles in snow cover (2-5 times), mineralization of snow meltwater (5-18 times), and the change of its ionic composition from calcium bicarbonate to calcium-sodium chloride (as compared with background snow cover).

Suspended forms of $\mathrm{Ca}, \mathrm{W}, \mathrm{Co}, \mathrm{V}, \mathrm{Sr}, \mathrm{Ti}, \mathrm{Mg}, \mathrm{Na}, \mathrm{Mo}, \mathrm{Zn}, \mathrm{Fe}, \mathrm{Sb}$, and $\mathrm{Cu}$ are primary pollutants in the traffic zone of the western part of Moscow; their concentrations in roadside snow cover are more than 25 times in excess over the background. $\mathrm{Na}, \mathrm{Sr}, \mathrm{Ca}, \mathrm{K}, \mathrm{Mo}, \mathrm{Sb}$, and $\mathrm{W}$ dominate among the dissolved forms, with six and more times excess over the background. The location of the anomalies of dissolved and suspended MMs concentrations matches those of the deposition of mentioned MMs forms in snow cover within the WAO. These anomalies are localized near the MRR and many large and medium roads. $\mathrm{Na}$ is the most important pollutant; its contribution to total deposition of pollutants increases with growing amount of DISs application-from $38-45 \%$ at the MO MSU and in the yards to $51-68 \%$ on the roads.

In WAO, the following anthropogenic sources supply different groups of chemical elements that form specific paragenetic associations of MMs in snow cover: DISs (dissolved Cl-Na-Sr-Ca and $\mathrm{Mg}-\mathrm{HCO}_{3}^{-}$); resuspension of road dust and blowing of soil particles (suspended $\mathrm{Ni}-\mathrm{Al}-\mathrm{Mg}-\mathrm{Ti}-\mathrm{Ca}-\mathrm{Sr}-\mathrm{Mn}-\mathrm{Co}-\mathrm{W}-\mathrm{K}-\mathrm{Rb}-\mathrm{Ba}-\mathrm{Ni}-\mathrm{Fe}-\mathrm{V}$ and dissolved Ti-Fe-Pb-Al-Sn-Bi-W); wear of metal parts of the cars (suspended $\mathrm{Cr}-\mathrm{Zn}, \mathrm{Mo}-\mathrm{Sb}-\mathrm{Cd}-\mathrm{As}$ and dissolved $\mathrm{Cr}-\mathrm{Ba}-\mathrm{Ni}, \mathrm{Mo}-\mathrm{Sb}-\mathrm{SO}_{4}{ }^{2-}$ ); abrasion of tires and roadway surfaces (dissolved $\mathrm{Mn}-\mathrm{Cd}-\mathrm{Cu}-\mathrm{Co}-\mathrm{Rb}$ ); vehicle exhausts (dissolved $\mathrm{K}-\mathrm{NO}_{3}{ }^{-}$); and emissions of heat power plants (dissolved $\mathrm{Mo}-\mathrm{Sb}-\mathrm{SO}_{4}{ }^{2-}$ ).

Author Contributions: All authors provided conceptualization and participated in writing the original draft and editing, D.V. performed statistical analysis of the geochemical data, D.V. and J.V. worked on the visualization, D.V. and N.K. (Natalia Kosheleva) collected the field data, N.K. (Natalia Kosheleva) and N.K. (Nikolay Kasimov) were responsible for funding acquisition, supervision, and project administration. All authors have read and agreed to the published version of the manuscript.

Funding: Research on snow cover pollution with MMs was financially supported by the Russian Geographical Society and Russian Foundation for Basic Research (contract number 03/2019/RGS-RFBR, project number 
17-05-41024 RGS_a). Investigation of MMs partitioning in snow cover was financially supported by the Russian Science Foundation (grant number 19-77-30004).

Acknowledgments: The authors express their gratitude to Mikhail Uzor, Dmitry Cherkasov, and Galina Shinkareva for assistance with the fieldwork; to Lilia Bezberdaya, Tatiana Dubrovskaya, Ksenia Nabelkina, and Alexander Ryzhov for help with laboratory measurements; and to Lyubov' Dobrydneva and Elena Terskaya for the analysis of ionic composition of snow.

Conflicts of Interest: The authors declare no conflict of interest.

\section{References}

1. World Health Organization. Burden of Disease from Ambient Air Pollution for 2012-Summary of Results; WHO: Geneva, Switzerland, 2014; 3p.

2. Raaschou-Nielsen, O.; Andersen, Z.J.; Beelen, R.; Samoli, E.; Stafoggia, M.; Weinmayr, G.; Hoffmann, B.; Fischer, P.; Nieuwenhuijsen, M.J.; Brunekreef, B.; et al. Air pollution and lung cancer incidence in 17 European cohorts: Prospective analyses from the European Study of Cohorts for Air Pollution Effects (ESCAPE). Lancet Oncol. 2013, 14, 813-822. [CrossRef]

3. Veremchuk, L.V.; Tsarouhas, K.; Vitkina, T.I.; Mineeva, E.E.; Gvozdenko, T.A.; Antonyuk, M.V.; Rakitskii, V.N.; Sidletskaya, K.A.; Tsatsakis, A.M.; Golokhvast, K.S. Impact evaluation of environmental factors on respiratory function of asthma patients living in urban territory. Environ. Pollut. 2018, 235, 489-496. [CrossRef] [PubMed]

4. Vasić, M.V.; Mihailović, A.; Kozmidis-Luburić, U.; Nemes, T.; Ninkov, J.; Zeremski-Škorić, T.; Antić, B. Metal contamination of short-term snow cover near urban crossroads: Correlation analysis of metal content and fine particles distribution. Chemosphere 2012, 86, 585-592. [CrossRef]

5. Yanchenko, N.I.; Sukhodolov, A.P.; Slutskii, S.L. Improving the monitoring of the snow cover for emission components from primary aluminum production. Metallurgist 2015, 59, 187-192. [CrossRef]

6. Moghadas, S.; Paus, K.H.; Muthanna, T.M.; Herrmann, I.; Marsalek, J.; Viklander, M. Accumulation of traffic-related trace metals in urban winter-long roadside snowbanks. Water Air Soil Pollut. 2015, 226, 404. [CrossRef]

7. Talovskaya, A.V.; Yazikov, E.G.; Filimonenko, E.A.; Lata, J.-C.; Kim, J.; Shakhova, T.S. Characterization of solid airborne particles deposited in snow in the vicinity of urban fossil fuel thermal power plant (Western Siberia). Environ. Technol. 2018, 39, 2288-2303. [CrossRef]

8. Gao, Y.; Yang, C.; Ma, J.; Yin, M. Characteristics of the trace elements and arsenic, iodine and bromine species in snow in east-central China. Atmos. Environ. 2018, 174, 43-53. [CrossRef]

9. Franz, T.P.; Eisenreich, S.J. Snow scavenging of polychlorinated biphenyls and polycyclic aromatic hydrocarbons in Minnesota. Environ. Sci. Technol. 1998, 32, 1771-1778. [CrossRef]

10. Sillanpää, N.; Koivusalo, H. Catchment-scale evaluation of pollution potential of urban snow at two residential catchments in southern Finland. Water Sci. Technol. 2013, 68, 2164-2170. [CrossRef]

11. Gustaytis, M.A.; Myagkaya, I.N.; Chumbaev, A.S. Hg in snow cover and snowmelt waters in high-sulfide tailing regions (Ursk tailing dump site, Kemerovo region, Russia). Chemosphere 2018, 202, 446-459. [CrossRef] [PubMed]

12. Chen, L.; Zhi, X.; Shen, Z.; Dai, Y.; Aini, G. Comparison between snowmelt-runoff and rainfall-runoff nonpoint source pollution in a typical urban catchment in Beijing, China. Environ. Sci. Pollut. Res. 2018, 25, 2377-2388. [CrossRef] [PubMed]

13. Telloli, C. Metal concentrations in snow samples in an urban area in the Po Valley. Int. J. Geosci. 2014, 5, 1116-1136. [CrossRef]

14. Huber, M.; Welker, A.; Helmreich, B. Critical review of heavy metal pollution of traffic area runoff: Occurrence, influencing factors, and partitioning. Sci. Total Environ. 2016, 541, 895-919. [CrossRef] [PubMed]

15. Galfi, H.; Österlund, H.; Marsalek, J.; Viklander, M. Mineral and anthropogenic indicator inorganics in urban stormwater and snowmelt runoff: Sources and mobility patterns. Water Air Soil Pollut. 2017, 228, 263. [CrossRef]

16. Vijayan, A.; Österlund, H.; Marsalek, J.; Viklander, M. Laboratory melting of late-winter urban snow samples: The magnitude and dynamics of releases of heavy metals and PAHs. Water Air Soil Pollut. 2019, $230,182$. [CrossRef] 
17. Zhao, X.; Guo, X.; Mao, Y.; Yan, H.; Li, M.; Zhao, L. Chemical and mineral characteristics of melted snow-water in the Jilin Province, North-East China. J. Civ. Environ. Eng. 2016, 6, 1000248. [CrossRef]

18. Golokhvast, K.S.; Manakov, Y.A.; Bykov, A.A.; Chayka, V.V.; Nikiforov, P.A.; Rogulin, R.S.; Romanova, T.Y.; Karabtsov, A.A.; Semenikhin, V.A. Some characteristics of dust particles in atmosphere of Kemerovo city according to pollution data of snow cover. IOP Conf. Ser. Earth Environ. Sci. 2017, 87, 042005. [CrossRef]

19. Nazarenko, Y.; Fournier, S.; Kurien, U.; Rangel-Alvarado, R.B.; Nepotchatykh, O.; Seers, P.; Ariya, P.A. Role of snow in the fate of gaseous and particulate exhaust pollutants from gasoline-powered vehicles. Environ. Pollut. 2017, 223, 665-675. [CrossRef]

20. Talovskaya, A.V.; Yazikov, E.G.; Osipova, N.A.; Lyapina, E.E.; Litay, V.V.; Metreveli, G.; Kim, J. Mercury pollution In snow cover around thermal power plants in cities (Omsk, Kemerovo, Tomsk Regions, Russia). Geogr. Environ. Sustain. 2019, 12, 132-147. [CrossRef]

21. Seleznev, A.; Yarmoshenko, I.; Malinovsky, G.; Ilgasheva, E.; Baglaeva, E.; Ryanskaya, A.; Kiseleva, D.; Gulyaeva, T. Snow-dirt sludge as an indicator of environmental and sedimentation processes in the urban environment. Sci. Rep. 2019, 9, 17241. [CrossRef]

22. Rangel-Alvarado, R.B.; Willis, C.E.; Kirk, J.L.; St Louis, V.L.; Amyot, M.; Bélanger, D.; Ariya, P.A. Athabasca oil sands region snow contains efficient micron and nano-sized ice nucleating particles. Environ. Pollut. 2019, 252, 289-295. [CrossRef] [PubMed]

23. Engelhard, C.; De Toffol, S.; Lek, I.; Rauch, W.; Dallinger, R. Environmental impacts of urban snow management-The alpine case study of Innsbruck. Sci. Total Environ. 2007, 382, 286-294. [CrossRef] [PubMed]

24. Ahmed, T.M.; Bergvall, C.; Westerholm, R. Emissions of particulate associated oxygenated and native polycyclic aromatic hydrocarbons from vehicles powered by ethanol/gasoline fuel blends. Fuel 2018, 214, 381-385. [CrossRef]

25. Charola, A.E.; Rousset, B.; Bläuer, C. Deicing salts: An overview. In Proceedings of the SWBSS 2017; Laue, S., Ed.; Verlag der Fachhochschule: Potsdam, Germany, 2017; pp. 16-23.

26. Ke, G.; Zhang, J.; Tian, B. Evaluation and selection of de-icing salt based on multi-factor. Materials 2019, 12, 912. [CrossRef]

27. Novotny, E.V.; Murphy, D.; Stefan, H.G. Increase of urban lake salinity by road deicing salt. Sci. Total Environ. 2008, 406, 131-144. [CrossRef]

28. Snieškienè, V.; Baležentienè, L.; Stankevičienè, A. Urban salt contamination impact on tree health and the prevalence of fungi agent in cities of the central Lithuania. Urban For. Urban Green. 2016, 19, 13-19. [CrossRef]

29. Nikiforova, E.M.; Kasimov, N.S.; Kosheleva, N.E. Long-term dynamics of the anthropogenic salinization of soils in Moscow (by the example of the Eastern district). Eurasian Soil Sci. 2014, 47, 203-215. [CrossRef]

30. Nikiforova, E.M.; Kasimov, N.S.; Kosheleva, N.E. Long-term dynamics of anthropogenic solonetzicity in soils of the Eastern okrug of Moscow under the impact of deicing salts. Eurasian Soil Sci. 2017, 50, 84-94. [CrossRef]

31. Ordóñez-Barona, C.; Sabetski, V.; Millward, A.A.; Steenberg, J. De-icing salt contamination reduces urban tree performance in structural soil cells. Environ. Pollut. 2018, 234, 562-571. [CrossRef]

32. Nelson, S.S.; Yonge, D.R.; Barber, M.E. Effects of road salts on heavy metal mobility in two Eastern Washington soils. J. Environ. Eng. 2009, 135, 505-510. [CrossRef]

33. Acosta, J.A.; Jansen, B.; Kalbitz, K.; Faz, A.; Martínez-Martínez, S. Salinity increases mobility of heavy metals in soils. Chemosphere 2011, 85, 1318-1324. [CrossRef] [PubMed]

34. Li, F.; Zhang, Y.; Fan, Z.; Oh, K. Accumulation of de-icing salts and its short-term effect on metal mobility in urban roadside soils. Bull. Environ. Contam. Toxicol. 2015, 94, 525-531. [CrossRef] [PubMed]

35. Kul'bachevskii, A.O. Report on the State of the Environment in Moscow in 2018; Department of Nature Management and Environmental Protection of Moscow Government: Moscow, Russia, 2019; 247p.

36. Bityukova, V.R.; Saulskaya, T.D. Changes of the anthropogenic impact of Moscow industrial zones during the recent decades. Vestn. Mosk. Unviersiteta Seriya Geogr. 2017, 3, 24-33.

37. Elansky, N.F.; Shilkin, A.V.; Ponomarev, N.A.; Semutnikova, E.G.; Zakharova, P.V. Weekly patterns and weekend effects of air pollution in the Moscow megacity. Atmos. Environ. 2020, 224, 117303. [CrossRef] 
38. Vinokurov, S.F.; Tarasova, N.P.; Trunova, A.N.; Sychkova, V.A. A comprehensive analysis of the content of heavy rare-earth elements and platinum in snow samples to assess the ecological hazard of air pollution in urban areas. Dokl. Earth Sci. 2017, 475, 771-774. [CrossRef]

39. Dryabzhinskiy, O.; Zubkova, V.; Lebedeva, M. The chemical composition of snow as a component of the environment in the South-Western administrative district of Moscow. In Proceedings of the 25th International Scientific Conference on Economic and Social Development-XVII International Social Congress (ISC-2017), Moscow, Russia, 30-31 October 2017; pp. 58-68.

40. Bogatyrev, L.G.; Zhilin, N.I.; Samsonova, V.P.; Yakushev, N.L.; Kirillova, N.P.; Benediktova, A.I.; Zemskov, P.I.; Karpuhin, M.M.; Ladonin, D.V.; Vartanov, A.N.; et al. Long-term monitoring of snow cover within natural and urbanized landscapes of the Moscow region. Vestn. Mosk. Unviersiteta Seriya Geogr. 2018, 2, 85-96.

41. Voronina, L.P.; Morachevskaya, E.V.; Akishina, M.M.; Kozlova, O.N. Evaluation of environmental health of the Kolomenskoye Park under anthropogenic pressure from Moscow City. J. Soils Sediments 2019, 19, 3226-3234. [CrossRef]

42. Khaustov, A.; Redina, M. Polycyclic aromatic hydrocarbons in the snow cover of Moscow (case study of the RUDN University campus). Polycycl. Aromat. Compd. 2019, 1-12. [CrossRef]

43. Sokolov, L.S.; Astrakhan, E.D. Contamination of Moscow area by metals. Priroda 1993, 7, 68-73.

44. Kasimov, N.S.; Perel'man, A.I.; Evseev, A.V.; Golubeva, N.I.; Nikiforova, E.M.; Lazukova, G.G. Ecogeochemistry of Urban Landscapes; Kasimov, N.S., Ed.; Moscow University Publishing House: Moscow, Russia, 1995; 336p.

45. Klimenko, I.A.; Poliakov, V.A.; Sokolovskiǔ, L.G.; Aksenova, O.I.; Skvortsova, O.I.; Okhrimenko, S.E. The sanitary status of natural waters on the territory of Moscow (according to the results of the examination of chemical and radionuclide composition). Gig. Sanit. 2003, 5, 7-11.

46. Kasimov, N.S.; Kosheleva, N.E.; Vlasov, D.V.; Terskaya, E.V. Geochemistry of snow cover within the Eastern district of Moscow. Vestn. Mosk. Unviersiteta Seriya Geogr. 2012, 4, 14-24.

47. Galitskaya, I.V.; Rumyantseva, N.A. Snow-cover contamination in urban territories (Lefortovo district, Moscow). Ann. Glaciol. 2012, 53, 23-26. [CrossRef]

48. Lebedev, A.T.; Polyakova, O.V.; Mazur, D.M.; Bol'shov, M.A.; Seregina, I.F. Estimation of contamination of atmosphere of Moscow in winter. J. Anal. Chem. 2012, 67, 1039-1049. [CrossRef]

49. Ermakov, A.A.; Karpova, E.A.; Malysheva, A.G.; Mikhaylova, R.I.; Ryzhova, I.N. Monitoring of the chemical composition of snow cover pollution in the Moscow region. Gig. Sanit. 2014, 5, 88-94.

50. Ermakov, A.A.; Karpova, E.A.; Malysheva, A.G.; Mikhaylova, R.I.; Ryzhova, I.N. Monitoring of the content of heavy metals and elements in the snow cover in agricultural soils at the territory of the Moscow region. Gig. Sanit. 2015, 94, 31-36.

51. Bobrovskiy, Y.V.; Boguslavskiy, M.V.; Bykov, V.N.; Vedenin, V.A.; Gadenin, M.M.; Glushkova, V.G.; Gorinov, M.M. Great Atlas of Moscow; Shmidt, S.O., Ed.; Feoriya: Moscow, Russia, 2013; ISBN 978-5-91796-032-6.

52. Yushkov, V.P.; Kurbatova, M.M.; Varentsov, M.I.; Lezina, E.A.; Kurbatov, G.A.; Miller, E.A.; Repina, I.A.; Artamonov, A.Y.; Kallistratova, M.A. Modeling an urban heat island during extreme frost in Moscow in January 2017. Izv. Atmos. Ocean. Phys. 2019, 55, 389-406. [CrossRef]

53. Lokoshchenko, M.A. Urban heat island and urban dry island in Moscow and their centennial changes. J. Appl. Meteorol. Climatol. 2017, 56, 2729-2745. [CrossRef]

54. Lokoshchenko, M.A. Snow cover and its modern changes in Moscow. Meteorol. Gidrol. 2005, 6, 71-82.

55. Kuoppamäki, K.; Setälä, H.; Rantalainen, A.-L.; Kotze, D.J. Urban snow indicates pollution originating from road traffic. Environ. Pollut. 2014, 195, 56-63. [CrossRef]

56. Yuan, D.; Liu, Y.; Guo, X.; Liu, J. Characteristic contaminants in snowpack and snowmelt surface runoff from different functional areas in Beijing, China. Environ. Sci. Pollut. Res. 2018, 25, 36256-36266. [CrossRef]

57. Cao, Z.; Zhou, X.; Ma, Y.; Wang, L.; Wu, R.; Chen, B.; Wang, W. The concentrations, formations, relationships and modeling of sulfate, nitrate and ammonium (SNA) aerosols over China. Aerosol Air Qual. Res. 2017, 17, 84-97. [CrossRef]

58. Eremina, I.D.; Vasil'chuk, J.Y. Temporal variations in chemical composition of snow cover in Moscow. Geogr. Environ. Sustain. 2019, 12, 148-158. [CrossRef]

59. NSAM № 499 AES/MS. Determination of the Elemental Composition of Rocks, Soils and Bottom Sediments by Atomic Emission and Mass Spectral Methods with Inductively Coupled Plasma; VIMS: Moscow, Russia, 2015. (In Russian) 
60. NSAM № 520 AES/MS. Determination of the Elemental Composition of Natural, Drinking, Sewage and Sea Waters by Atomic Emission and Mass Spectral Methods with Inductively Coupled Plasma; VIMS: Moscow, Russia, 2017. (In Russian)

61. Saet, Y.E.; Revich, B.A.; Yanin, E.P.; Smirnova, R.S.; Basharkevich, E.L.; Onischenko, T.L.; Pavlova, L.N.; Trefilova, N.Y.; Achkasov, A.I.; Sarkisyan, S.S. Geochemistry of the Environment; Nedra: Moscow, Russia, 1990; ISBN 5-247-01127-9.

62. Kasimov, N.S.; Kosheleva, N.E.; Nikiforova, E.M.; Vlasov, D.V. Benzo[a]pyrene in urban environments of eastern Moscow: Pollution levels and critical loads. Atmos. Chem. Phys. 2017, 17, 2217-2227. [CrossRef]

63. Eremina, I.D.; Grigoriev, A.V. Acidity and chemical composition of snow cover in the city of Moscow and the Moscow region during 1999-2006. Vestn. Mosk. Unviersiteta Seriya Geogr. 2010, 3, 55-60.

64. Johnson, C.C.; Demetriades, A.; Allen, M.A.; Cave, M.R.; Chenery, S.R.N.; Gowing, C.J.B.; Reeder, S.; Harrison, I. Mapping the Chemical Environment of Urban Areas; Johnson, C.C., Demetriades, A., Locutura, J., Ottesen, R.T., Eds.; John Wiley \& Sons, Ltd.: Chichester, UK, 2011; ISBN 978-0-470-67007-1.

65. Prokof'eva, T.V.; Kiryushin, A.V.; Shishkov, V.A.; Ivannikov, F.A. The importance of dust material in urban soil formation: The experience on study of two young Technosols on dust depositions. J. Soils Sediments 2017, 17, 515-524. [CrossRef]

66. Prokof'eva, T.; Shishkov, V.; Kiriushin, A. Calcium carbonate accumulations in Technosols of Moscow city. J. Soils Sediments 2020, 1-10. [CrossRef]

67. Kasimov, N.S.; Vlasov, D.V.; Kosheleva, N.E. Enrichment of road dust particles and adjacent environments with metals and metalloids in eastern Moscow. Urban Clim. 2020, 32, 100638. [CrossRef]

68. Kasimov, N.S.; Kosheleva, N.E.; Vlasov, D.V.; Nabelkina, K.S.; Ryzhov, A.V. Physicochemical properties of road dust in Moscow. Geogr. Environ. Sustain. 2019, 12, 96-113. [CrossRef]

69. Vlasov, D.V.; Shinkareva, G.L.; Kasimov, N.S. Metals and metalloids in bottom sediments of lakes and ponds of the eastern part of Moscow. Vestn. Mosk. Unviersiteta Seriya Geogr. 2019, 4, 43-52.

70. Greinert, A.; Fruzińska, R.; Kostecki, J. Urban soils in Zielona Góra. In Technogenic Soils of Poland; Charzyński, P., Hulisz, P., Bednarek, R., Eds.; Polish Society of Soil Science: Torun, Poland, 2013; pp. 31-54.

71. Karanasiou, A.; Amato, F.; Moreno, T.; Lumbreras, J.; Borge, R.; Linares, C.; Boldo, E.; Alastuey, A.; Querol, X. Road dust emission sources and assessment of street washing effect. Aerosol Air Qual. Res. 2014, 14, 734-743. [CrossRef]

72. Amato, F.; Alastuey, A.; de la Rosa, J.; Gonzalez Castanedo, Y.; Sánchez de la Campa, A.M.; Pandolfi, M.; Lozano, A.; Contreras González, J.; Querol, X. Trends of road dust emissions contributions on ambient air particulate levels at rural, urban and industrial sites in southern Spain. Atmos. Chem. Phys. 2014, 14, 3533-3544. [CrossRef]

73. Ramírez, O.; Sánchez de la Campa, A.M.; Amato, F.; Moreno, T.; Silva, L.F.; de la Rosa, J.D. Physicochemical characterization and sources of the thoracic fraction of road dust in a Latin American megacity. Sci. Total Environ. 2019, 652, 434-446. [CrossRef] [PubMed]

74. Singh, S.; Elumalai, S.P.; Pal, A.K. Rain pH estimation based on the particulate matter pollutants and wet deposition study. Sci. Total Environ. 2016, 563-564, 293-301. [CrossRef]

75. Kasimov, N.S.; Vlasov, D.V.; Kosheleva, N.E.; Nikiforova, E.M. Geochemistry of Landscapes of Eastern Moscow; APR: Moscow, Russia, 2016; ISBN 978-5-904761-62-2.

76. Eremina, I.D.; Aloyan, A.E.; Arutyunyan, V.O.; Larin, I.K.; Chubarova, N.E.; Yermakov, A.N. Acidity and mineral composition of precipitation in Moscow: Influence of deicing salts. Izv. Atmos. Ocean. Phys. 2015, 51, 624-632. [CrossRef]

77. Elansky, N.F.; Ponomarev, N.A.; Verevkin, Y.M. Air quality and pollutant emissions in the Moscow megacity in 2005-2014. Atmos. Environ. 2018, 175, 54-64. [CrossRef]

78. Eremina, I.D. Chemical composition of atmospheric precipitation in Moscow and the trends of its long-term changes. Vestn. Mosk. Unviersiteta Seriya Geogr. 2019, 3, 3-10.

79. Reimann, C.; Filzmoser, P.; Garrett, R.G.; Dutter, R. Statistical Data Analysis Explained: Applied Environmental Statistics with R; John Wiley \& Sons, Ltd.: Chichester, UK, 2008.

80. Alves, C.A.; Barbosa, C.; Rocha, S.; Calvo, A.; Nunes, T.; Cerqueira, M.; Pio, C.; Karanasiou, A.; Querol, X. Elements and polycyclic aromatic hydrocarbons in exhaust particles emitted by light-duty vehicles. Environ. Sci. Pollut. Res. 2015, 22, 11526-11542. [CrossRef] 
81. Hung-Lung, C.; Yao-Sheng, H. Particulate matter emissions from on-road vehicles in a freeway tunnel study. Atmos. Environ. 2009, 43, 4014-4022. [CrossRef]

82. Chiang, H.-L.; Lai, Y.-M.; Chang, S.-Y. Pollutant constituents of exhaust emitted from light-duty diesel vehicles. Atmos. Environ. 2012, 47,399-406. [CrossRef]

83. Almeida, S.; Pio, C.; Freitas, M.; Reis, M.; Trancoso, M. Source apportionment of fine and coarse particulate matter in a sub-urban area at the Western European Coast. Atmos. Environ. 2005, 39, 3127-3138. [CrossRef]

84. Jiang, S.Y.; Kaul, D.S.; Yang, F.; Sun, L.; Ning, Z. Source apportionment and water solubility of metals in size segregated particles in urban environments. Sci. Total Environ. 2015, 533, 347-355. [CrossRef] [PubMed]

85. Spencer, M.T.; Shields, L.G.; Sodeman, D.A.; Toner, S.M.; Prather, K.A. Comparison of oil and fuel particle chemical signatures with particle emissions from heavy and light duty vehicles. Atmos. Environ. 2006, 40, 5224-5235. [CrossRef]

86. Cross, E.S.; Sappok, A.; Fortner, E.C.; Hunter, J.F.; Jayne, J.T.; Brooks, W.A.; Onasch, T.B.; Wong, V.W.; Trimborn, A.; Worsnop, D.R.; et al. Real-time measurements of engine-out trace elements: Application of a novel soot particle aerosol mass spectrometer for emissions characterization. J. Eng. Gas Turbines Power 2012, 134, 072801. [CrossRef]

87. Pio, C.; Mirante, F.; Oliveira, C.; Matos, M.; Caseiro, A.; Oliveira, C.; Querol, X.; Alves, C.; Martins, N.; Cerqueira, M.; et al. Size-segregated chemical composition of aerosol emissions in an urban road tunnel in Portugal. Atmos. Environ. 2013, 71, 15-25. [CrossRef]

88. Al-Momani, I. Trace elements in atmospheric precipitation at Northern Jordan measured by ICP-MS: Acidity and possible sources. Atmos. Environ. 2003, 37, 4507-4515. [CrossRef]

89. Song, F.; Gao, Y. Size distributions of trace elements associated with ambient particular matter in the affinity of a major highway in the New Jersey-New York metropolitan area. Atmos. Environ. 2011, 45, 6714-6723. [CrossRef]

90. Hu, S.; Herner, J.D.; Shafer, M.; Robertson, W.; Schauer, J.J.; Dwyer, H.; Collins, J.; Huai, T.; Ayala, A. Metals emitted from heavy-duty diesel vehicles equipped with advanced PM and NOX emission controls. Atmos. Environ. 2009, 43, 2950-2959. [CrossRef]

91. Pant, P.; Harrison, R.M. Estimation of the contribution of road traffic emissions to particulate matter concentrations from field measurements: A review. Atmos. Environ. 2013, 77, 78-97. [CrossRef]

92. Grigoratos, T.; Martini, G. Brake wear particle emissions: A review. Environ. Sci. Pollut. Res. 2015, 22, 2491-2504. [CrossRef]

93. Penkała, M.; Ogrodnik, P.; Rogula-Kozłowska, W. Particulate matter from the road surface abrasion as a problem of non-exhaust emission control. Environments 2018, 5, 9. [CrossRef]

94. Bencharif-Madani, F.; Ali-Khodja, H.; Kemmouche, A.; Terrouche, A.; Lokorai, K.; Naidja, L.; Bouziane, M. Mass concentrations, seasonal variations, chemical compositions and element sources of PM10 at an urban site in Constantine, northeast Algeria. J. Geochem. Explor. 2019, 206, 106356. [CrossRef]

95. Vlasov, D.V.; Kasimov, N.S.; Kosheleva, N.E. Geochemistry of the road dust in the Eastern district of Moscow. Vestn. Mosk. Unviersiteta Seriya Geogr. 2015, 1, 23-33.

96. Vlasov, D.V. Metals and metalloids in PM10 fraction of the road dust of Eastern Moscow. RUDN J. Ecol. Life Saf. 2017, 25, 529-539. [CrossRef]

97. Ermolin, M.S.; Fedotov, P.S.; Ivaneev, A.I.; Karandashev, V.K.; Fedyunina, N.N.; Burmistrov, A.A. A contribution of nanoscale particles of road-deposited sediments to the pollution of urban runoff by heavy metals. Chemosphere 2018, 210, 65-75. [CrossRef] [PubMed]

98. Krivcov, V.A.; Tobratov, S.A.; Vozorezov, A.V.; Komarov, M.M.; Zheleznova, O.S.; Solov'eva, E.A. The Natural Potential of the Landscapes of the Ryazan Oblast; Ryazan State University Named for S. Yesenin: Ryazan, Russia, 2011.

99. Grotti, M.; Soggia, F.; Ardini, F.; Magi, E. Major and trace element partitioning between dissolved and particulate phases in Antarctic surface snow. J. Environ. Monit. 2011, 13, 2511. [CrossRef]

100. Kosheleva, N.E.; Vlasov, D.V.; Korlyakov, I.D.; Kasimov, N.S. Contamination of urban soils with heavy metals in Moscow as affected by building development. Sci. Total Environ. 2018, 636, 854-863. [CrossRef]

101. Ramírez, O.; Sánchez de la Campa, A.M.; Amato, F.; Catacolí, R.A.; Rojas, N.Y.; de la Rosa, J. Chemical composition and source apportionment of PM10 at an urban background site in a high-altitude Latin American megacity (Bogota, Colombia). Environ. Pollut. 2018, 233, 142-155. [CrossRef] 
102. United States Environmental Protection Agency National Emissions Inventory 2017. Available online: https://www.epa.gov/air-emissions-inventories/2017-national-emissions-inventory-nei-data (accessed on 21 March 2020).

103. Amato, F.; Favez, O.; Pandolfi, M.; Alastuey, A.; Querol, X.; Moukhtar, S.; Bruge, B.; Verlhac, S.; Orza, J.A.G.; Bonnaire, N.; et al. Traffic induced particle resuspension in Paris: Emission factors and source contributions. Atmos. Environ. 2016, 129, 114-124. [CrossRef]

104. Emelyanov, E.M. Physicochemical barriers. In The Barrier Zones in the Ocean; Springer: Berlin/Heidelberg, Germany, 2005; pp. 15-24. ISBN 978-3-540-25391-4.

105. Bauer, S.; Conrad, S.; Ingri, J. Geochemistry of tungsten and molybdenum during freshwater transport and estuarine mixing. Appl. Geochem. 2018, 93, 36-48. [CrossRef]

106. Adamiec, E.; Wieszała, R.; Strzebońska, M.; Jarosz-Krzemińska, E. An attempt to identify traffic related elements in snow. Geol. Geophys. Environ. 2013, 39, 317. [CrossRef]

107. Zhang, L.; Michelangeli, D.V.; Taylor, P.A. Numerical studies of aerosol scavenging by low-level, warm stratiform clouds and precipitation. Atmos. Environ. 2004, 38, 4653-4665. [CrossRef]

108. Di Marco, V.; Tapparo, A.; Badocco, D.; D'Aronco, S.; Pastore, P.; Giorio, C. Metal ion release from fine particulate matter sampled in the Po Valley to an aqueous solution mimicking fog water: Kinetics and solubility. Aerosol Air Qual. Res. 2020, 20, 720-729. [CrossRef]

109. Kasimov, N.S.; Lychagin, M.Y.; Chalov, S.R.; Shinkareva, G.L. Paragenetic associations of chemical elements in landscapes. Vestn. Mosk. Unviersiteta Seriya Geogr. 2019, 6, 20-28.

110. Pan, Y.P.; Wang, Y.S. Atmospheric wet and dry deposition of trace elements at 10 sites in Northern China. Atmos. Chem. Phys. 2015, 15, 951-972. [CrossRef]

111. Carling, G.T.; Fernandez, D.P.; Johnson, W.P. Dust-mediated loading of trace and major elements to Wasatch Mountain snowpack. Sci. Total Environ. 2012, 432, 65-77. [CrossRef] [PubMed]

112. Dinu, M.; Moiseenko, T.; Baranov, D. Snowpack as indicators of atmospheric pollution: The Valday Upland. Atmosphere 2020, 11, 462. [CrossRef]

113. Westerlund, C.; Viklander, M.; Bäckström, M. Seasonal variations in road runoff quality in Luleå, Sweden. Water Sci. Technol. 2003, 48, 93-101. [CrossRef]

114. Rangel-Alvarado, R.B.; Nazarenko, Y.; Ariya, P.A. Snow-borne nanosized particles: Abundance, distribution, composition, and significance in ice nucleation processes. J. Geophys. Res. Atmos. 2015, 120, 11760-11774. [CrossRef]

115. Göbel, P.; Dierkes, C.; Coldewey, W.G. Storm water runoff concentration matrix for urban areas. J. Contam. Hydrol. 2007, 91, 26-42. [CrossRef]

116. Sister, V.; Koretsky, V. Engineering-Environmental Protection of Water System of the Northern Megapolis in Winter Period; Center MSUIE: Moscow, Russia, 2004.

117. Borsato, A.; Johnston, V.E.; Frisia, S.; Miorandi, R.; Corradini, F. Temperature and altitudinal influence on karst dripwater chemistry: Implications for regional-scale palaeoclimate reconstructions from speleothems. Geochim. Cosmochim. Acta 2016, 177, 275-297. [CrossRef]

118. Fabretti, J.-F.; Sauret, N.; Gal, J.-F.; Maria, P.-C.; Schärer, U. Elemental characterization and source identification of PM2.5 using Positive Matrix Factorization: The Malraux road tunnel, Nice, France. Atmos. Res. 2009, 94 , 320-329. [CrossRef]

119. Lawrence, S.; Sokhi, R.; Ravindra, K. Quantification of vehicle fleet PM10 particulate matter emission factors from exhaust and non-exhaust sources using tunnel measurement techniques. Environ. Pollut. 2016, 210, 419-428. [CrossRef] [PubMed]

120. Morera-Gómez, Y.; Alonso-Hernández, C.M.; Santamaría, J.M.; Elustondo, D.; Lasheras, E.; Widory, D. Levels, spatial distribution, risk assessment, and sources of environmental contamination vectored by road dust in Cienfuegos (Cuba) revealed by chemical and C and N stable isotope compositions. Environ. Sci. Pollut. Res. 2020, 27, 2184-2196. [CrossRef] [PubMed]

121. Tanner, P.A.; Ma, H.-L.; Yu, P.K.N. Fingerprinting metals in urban street dust of Beijing, Shanghai, and Hong Kong. Environ. Sci. Technol. 2008, 42, 7111-7117. [CrossRef]

122. Apeagyei, E.; Bank, M.S.; Spengler, J.D. Distribution of heavy metals in road dust along an urban-rural gradient in Massachusetts. Atmos. Environ. 2011, 45, 2310-2323. [CrossRef]

123. Adamiec, E.; Jarosz-Krzemińska, E.; Wieszała, R. Heavy metals from non-exhaust vehicle emissions in urban and motorway road dusts. Environ. Monit. Assess. 2016, 188, 369. [CrossRef] 
124. Kasimov, N.S.; Bezberdaya, L.A.; Vlasov, D.V.; Lychagin, M.Y. Metals, metalloids, and benzo[a]pyrene in PM10 particles of soils and road dust of Alushta city. Eurasian Soil Sci. 2019, 52, 1608-1621. [CrossRef]

125. Konstantinova, E.; Minkina, T.; Konstantinov, A.; Sushkova, S.; Antonenko, E.; Kurasova, A.; Loiko, S. Pollution status and human health risk assessment of potentially toxic elements and polycyclic aromatic hydrocarbons in urban street dust of Tyumen city, Russia. Environ. Geochem. Health 2020, 1-24. [CrossRef]

126. Wahlin, P.; Berkowicz, R.; Palmgren, F. Characterisation of traffic-generated particulate matter in Copenhagen. Atmos. Environ. 2006, 40, 2151-2159. [CrossRef]

127. Thorpe, A.; Harrison, R.M. Sources and properties of non-exhaust particulate matter from road traffic: A review. Sci. Total Environ. 2008, 400, 270-282. [CrossRef]

128. Amato, F.; Pandolfi, M.; Moreno, T.; Furger, M.; Pey, J.; Alastuey, A.; Bukowiecki, N.; Prevot, A.S.H.; Baltensperger, U.; Querol, X. Sources and variability of inhalable road dust particles in three European cities. Atmos. Environ. 2011, 45, 6777-6787. [CrossRef]

129. Hulskotte, J.H.J.; Roskam, G.D.; Denier van der Gon, H.A.C. Elemental composition of current automotive braking materials and derived air emission factors. Atmos. Environ. 2014, 99, 436-445. [CrossRef]

130. Goddard, S.L.; Williams, K.R.; Robins, C.; Brown, R.J.C. Determination of antimony and barium in UK air quality samples as indicators of non-exhaust traffic emissions. Environ. Monit. Assess. 2019, 191, 641. [CrossRef] [PubMed]

131. Sanders, P.G.; Xu, N.; Dalka, T.M.; Maricq, M.M. Airborne brake wear debris: Size distributions, composition, and a comparison of dynamometer and vehicle tests. Environ. Sci. Technol. 2003, 37, 4060-4069. [CrossRef]

132. Reid, J.S.; Koppmann, R.; Eck, T.F.; Eleuterio, D.P. A review of biomass burning emissions part II: Intensive physical properties of biomass burning particles. Atmos. Chem. Phys. 2005, 5, 799-825. [CrossRef]

133. Grivas, G.; Cheristanidis, S.; Chaloulakou, A.; Koutrakis, P.; Mihalopoulos, N. Elemental composition and source apportionment of fine and coarse particles at traffic and urban background locations in Athens, Greece. Aerosol Air Qual. Res. 2018, 18, 1642-1659. [CrossRef]

134. Achad, M.; Caumo, S.; de Castro Vasconcellos, P.; Bajano, H.; Gómez, D.; Smichowski, P. Chemical markers of biomass burning: Determination of levoglucosan, and potassium in size-classified atmospheric aerosols collected in Buenos Aires, Argentina by different analytical techniques. Microchem. J. 2018, 139, 181-187. [CrossRef]

(C) 2020 by the authors. Licensee MDPI, Basel, Switzerland. This article is an open access article distributed under the terms and conditions of the Creative Commons Attribution (CC BY) license (http://creativecommons.org/licenses/by/4.0/). 